\title{
EXHIBIR Y RESIGNIFICAR. REINTERPRETACIONES DE LOS RESTOS ARQUEOLÓGICOS OLMECAS ENTRE LOS SIGLOS XIX Y XX
}

\author{
Haydeé López Hernández \\ Instituto Nacional de Antropología e Historia
}

\begin{abstract}
T as interpretaciones de los objetos arqueológicos, al Ligual que la historia, pueden y deben ser sujetas a una revisión historiográfica que permita observar sus diferentes configuraciones, así como los lugares que ocuparon en la historia nacional y en los espacios museográficos, tanto a nivel nacional como en las localidades. El caso de los significados de las piezas hoy conocidas como olmecas, propongo, no es la excepción, sino que muestra el tránsito de los intereses de la universalidad decimonónica a los anhelos del chauvinismo posrevolucionario de entreguerras. Las piezas fueron interpretadas en el siglo XIX como evidencia de la presencia negra en el continente, como referentes de Tezcatlipoca, y como una muestra de los contactos del continente con África y Asia. Aun cuando pocos estudiosos sostuvieron estas propuestas, las piezas fueron elementos
\end{abstract}

Fecha de recepción: 30 de septiembre de 2014 Fecha de aceptación: 11 de febrero de 2015 
fundamentales para sostener la universalidad de la historia patria desde el siglo XIx. Sin embargo, tales objetos no ingresaron al discurso museográfico de los salones del Museo Nacional, en la capital del país, porque la presencia negra en el continente no era un argumento válido para la historia nacional que se estaba delineando. Por ello, las piezas olmecas sólo ingresaron al recinto museográfico a mediados del siglo xx, cuando fueron reconocidos como realidades autóctonas, como la "cultura madre".

Las nuevas valoraciones del arte también incidieron en las definiciones académicas. En el momento en que Occidente se empeñaba por encontrar la universalidad en la diferencia, en el arte y en lo exótico, la simpleza y antigüedad de las piezas prehispánicas resultaron un arma valiosa para su ingreso parcial a los espacios de exhibición. Estas modificaciones en la valoración de las piezas también permearon el discurso histórico y la apreciación del patrimonio y su protección. Gracias a este contexto de entreguerras, los restos arqueológicos olmecas fueron mostrados en el Museo Nacional aunque, al final, resultaron demasiado "primitivos", o quizá demasiado ajenos y diferentes al resto de la historia prehispánica, como para obtener una posición encumbrada frente a la historia maya y la mexica.

Finalmente, la injerencia de los actores políticos e intelectuales también influyó en la resignificación y valoración de las piezas, porque no obstante que en el orden del mundo científico tales piezas no ocuparon el espacio central de la historia, en el del universo sensible del espíritu humano sí tuvieron una esfera propia y prioritaria, sobre todo en las localidades que apelaban por su reconocimiento en la orquesta universal. 


\section{LO UNIVERSAL}

El coleccionismo de las naciones modernas está profundamente vinculado con las ambiciones colonialistas de las potencias, y bajo esta perspectiva se fundaron las mayores colecciones de objetos no occidentales en Europa. El tránsito de las colecciones de curiosidades de las monarquías a los museos públicos era parte del programa que buscaba la laicización del conocimiento por un lado y, por el otro, la construcción del nuevo hombre, el ciudadano. ${ }^{1}$ Así los museos se convirtieron en una recreación de la naturaleza y del pasado, exhibiendo en sus vitrinas una muestra representativa del orden natural por medio de taxonomías. La construcción de este ideal estético, científico e histórico arrancó desde el siglo XviII y sus transformaciones nos acompañan incluso hasta hoy.

Los primeros museos públicos del Viejo Continente se esforzaron por instaurar un discurso de reordenamiento y clasificación del mundo, tanto de la esfera natural como de la del arte. En este ámbito no estaban consideradas las culturas prehistóricas europeas, las cuales, sólo décadas más tarde, adquirieron un espacio propio gracias al nuevo discurso antropológico. El prototipo por excelencia de los museos fue el Museo del Louvre y, en éste, se reordenaron y estandarizaron los esquemas visuales, y se instauraron nuevos valores estéticos y de clasificación, colocando en la cima a las obras del arte clásico de Italia, Inglaterra y, por supuesto, Francia. ${ }^{2}$

${ }^{1}$ Fue en este marco que tuvo cabida la creación de los congresos de americanistas. Véase Congrés international des Américanistes.

${ }^{2}$ Un análisis sobre las primeras colecciones del Museo del Louvre en Duncan, "From the Princely", pp. 304-331. Rydell, "The Chicago 
México no fue ajeno a estas inquietudes y en sus acervos, además, la cuestión colonialista se entretejió con la de la construcción y la fundamentación de la historia patria. ${ }^{3}$ A partir de la segunda mitad del siglo xIx, el discurso científico retomó la preocupación sobre el papel de América en el pasado de la humanidad, integrando el continente a la narrativa histórica y natural. ${ }^{4}$ Fueron los salones del Museo Nacional los encargados de tal tarea. ${ }^{5} \mathrm{Al}$ parecer, uno de los primeros intentos de ordenamiento de las colecciones arqueológicas lo realizó Fernando Ramírez al hacer la descripción de 43 piezas para México y sus alrededores, a solicitud del presidente Ignacio Comonfort. ${ }^{6}$ Años después, con la apertura de la Sala de Monolitos, las piezas del pasado precolombino adquirieron un lugar privilegiado en el Museo Nacional.

World's Columbian Exposition of 1893”, pp. 273-303, por su parte, muestra el tránsito entre las ferias y los espacios museográficos y de exhibición nacionales.

${ }^{3}$ Son numerosos los trabajos que analizan la construcción de la historia patria desde el siglo xIx, así como su relación con la identidad nacional. Véanse por ejemplo Pérez Vejo, España en el debate público mexicano; Rozat, Los orígenes de la nación.

${ }^{4}$ Hago referencia al término narrativa para enfatizar el proceso de construcción del discurso histórico y, por tanto, a sus transformaciones en el tiempo de acuerdo con su contexto de formación. En este sentido, tanto para el discurso escrito como para el museográfico o de exhibición, no podemos hablar de una sola Historia (con mayúscula), sino de historias (en plural), es decir, de diferentes narrativas.

${ }^{5}$ Son varios los autores que han analizado la vida del Museo Nacional. Véanse, por ejemplo, Castro-Leal y Sierra, "Museo Nacional de Antropología”, pp. 511-559; Morales Moreno, Orígenes de la museología mexicana; Pérez Montfort, "El Museo Nacional”, pp. 27-31; Rico MANSARD, Exhibir para educar y RUTSCH, Entre el campo y el gabinete. ${ }^{6}$ Rico Mansard, Exhibir, para educar, p. 118. 
Una de las pocas instantáneas que perviven de estos momentos nos la ofrece la descripción de la visita que hicieran al Museo Nacional los asistentes al Congreso Internacional de Americanistas celebrado en la ciudad de México:

En ese lugar se hallan como principales, la gran piedra llamada Calendario Azteca ó Piedra del Sol; la cabeza colosal de diorita que representa, en el sentir del Sr. Chavero, el dios Totec; la gran estatua encontrada en las ruinas de Chichen-Itza por el Dr. Le Plongeon, y que lleva el nombre de Chac-Mool; la colosal de la diosa Coatlicue, descubierta en la Plaza mayor de México a fines del pasado siglo; la gran piedra de Tizoc; las dos cabezas colosales de serpiente desenterradas en el atrio de la Catedral de México en 1881 por el Sr. Garcia Cubas; las grandes columnas toltecas, en fragmentos; la estatua conocida por del Indio triste; [...] y el colosal monolito traído de Teotihuacán por el Sr. D. Leopoldo Batres, Inspector de los monumentos de la República. ${ }^{7}$

Los congresistas pudieron observar 354 esculturas y las piezas de la sección de cerámica, localizada en una de las alas de la planta baja del edificio de Moneda. México, al igual que el resto de las naciones que aspiraban al establecimiento del ideal moderno y universalista, adaptó su historia patria al devenir occidental -universal y bíblico-. Sin embargo, a diferencia de Europa, que no integró la prehistoria en la exhibición de sus culturas clásicas, los estudiosos mexicanos integraron las piezas del pasado prehispánico en el discurso del orden de la naturaleza y de la historia dentro del Museo Nacional desde su inicio, en 1825. Es cierto que

7 "Visita al Museo Nacional", p. 37. 
el reconocimiento de estas piezas fue ambivalente respecto a su posible valor estético, al menos durante todo el siglo XIX, pero los estudiosos siempre se esforzaron por fundamentar el valor histórico de todas las piezas, incluso de las más remotas.

Varios autores han destacado que durante todo el siglo xIx prevaleció el desorden de las colecciones arqueológicas en el Museo Nacional. ${ }^{8}$ Partiendo del criterio actual sobre el orden histórico, en las pocas imágenes que se conservan de aquel entonces, las piezas aparecen como una amalgama informe en salas completamente abarrotadas y carentes de orden. Sin embargo, esto desvela la gran cantidad de piezas, la complejidad del espectro del pasado y un diferente criterio sobre el ordenamiento científico. El acomodo de las piezas no era de ninguna manera una tarea natural que resultara evidente a los ojos de los encargados de su estudio. Cada una de éstas fue dispuesta y recolocada en diversas ocasiones, siguiendo el ritmo siempre cambiante de la historia nacional y de los criterios científicos y museográficos. ${ }^{9}$

8 Por ejemplo Pérez Montfort, “El Museo Nacional”, p. 27, señala que, al menos hasta 1867, el establecimiento era "un museo-depósito de objetos diversos", cuando se transformó en el "baluarte del nacionalismo cívico y patriótico".

${ }^{9}$ Son varios los estudios sobre las colecciones del Museo Nacional. Por ejemplo, Pérez Montfort, “El Museo Nacional” y Morales Moreno, Orígenes de la museología, abordan el carácter nacionalista del discurso de las colecciones. RUTSCH, Entre el campo y el gabinete, además analiza parte de la complejidad que representó el reordenamiento de aquéllas por parte de un extranjero como Eduard Seler, mientras que Rico MANSARD, Exhibir para educar, habla sobre el papel educativo de la institución. Aún queda pendiente observar las colecciones como parte del discurso científico, es decir, como objetos del conocimiento que continuamente están (re)configurándose. Cabe aclarar que, hasta bien entrado el siglo xIx, sólo las esculturas y las figurillas -y no los tiestos de cerámica- 
Los estudiosos buscaban resaltar el significado de las piezas echando mano de su orden y su disposición en cada una de las vitrinas. Esta tarea sin duda fue más sencilla para las antigüedades de los pueblos más estudiados, como el azteca por ejemplo, pero las piezas hoy conocidas como olmecas no corrieron la misma suerte. Si bien la cabeza de Hueyapan fue conocida desde la segunda mitad del siglo xIx, no existió interés por su exhibición porque no había ningún consenso sobre su significado en la historia prehispánica. La pieza fue dada a conocer al mundo científico desde 1868 por José María Melgar y Serrano. ${ }^{10}$ Basado en los rasgos físicos de la pieza y en el análisis de las obras de Boturini, Humboldt y Orozco y Berra, el autor propuso que la cabeza era la prueba de la presencia de la raza negra en el continente americano. ${ }^{11}$

No obstante, pocos fueron los autores que se sumaron a esta propuesta. Alfredo Chavero, por ejemplo, en México

se consideraban datos de valor científico y, por tanto, exhibibles. A partir de este criterio, las piezas se agrupaban de acuerdo con su semejanza estilística. De esta forma, piezas procedentes de la costa del Golfo podían encontrarse al lado de objetos de Teotihuacan, porque ambas, a los ojos de los investigadores, tenían los mismos rasgos. Un criterio totalmente diferente usó, por ejemplo, Eduard Seler cuando se encargó de ordenar las colecciones del Museo Nacional bajo un "criterio histórico contextual”, es decir, de acuerdo con su procedencia geográfica. Sobre la clasificación de Seler véase RuTsch, Entre el campo y el gabinete, pp. 118 ss. Años después, George Vaillant también mostraría su desacuerdo con las clasificaciones de los estudiosos mexicanos para definir el "archaic problem”. Véase Vaillant, "Excavations at Zacatenco”, pp. 15 ss.

10 Melgar y Serrano dio a conocer la cabeza de Hueyapan en 1868 en el Semanario Ilustrado y más tarde en el Boletín de la Sociedad de Geografía y Estadística de la República Mexicana. Véase Melgar y Serrano, "Antigüedades mexicanas" y "Estudio sobre la antigüedad y el origen". ${ }^{11}$ Melgar se basa principalmente en la Idea de una nueva historia de América Septentrional (1746) de Boturini. 
a través de los siglos, incluyó el grabado de la pieza que publicara Melgar, asegurando que era la prueba de que en tiempos prehistóricos los continentes se encontraban unidos por medio de la Atlántida y de que la raza negra migró al continente americano. ${ }^{12}$ Por otro lado, algunos lustros después, en 1916, un profesor del Museo Nacional, Ramón Mena, realizó una inspección a Tabasco y pudo observar una escultura conservada en el Instituto Juárez, de la que aseguraba tenía rasgos negroides. ${ }^{13}$

Por su parte, Marshall Howard Saville se encontraba profundamente interesado en la región de los Tuxtlas, pero sólo en las hachas votivas, de las que pensaba que estaban vinculadas con el culto de Tezcatlipoca, y posiblemente también con la Estatuilla de los Tuxtlas (presumiblemente procedente de esta región), cuya fecha calendárica maya era la más remota conocida hasta entonces. ${ }^{14}$ Algunos de sus contemporáneos estadounidenses, además, estaban interesados en la misma región, pero por sus posibles contactos con las zonas maya y la del Mississippi, las cuales, consideraban, estuvieron vinculadas por migraciones. ${ }^{15}$

12 Chavero, "Primera época. Historia antigua”.

13 ATA, t. CVI, exp. 825, s. f.

14 Aun cuando varios autores han considerado que el estudio de Saville es precursor en la identificación de lo olmeca, cabría resaltar que Saville agrupa estos objetos y otros resaltando su similitud con los rasgos de un tigre y, por tanto, por su posible relación con Tezcatlipoca. En 1929, Saville, "Votives Axes from Ancient Mexico", pp. 335-342, ubica cuatro hachas en el American Museum of Natural History, una en el British Museum, una en el Peabody Museum, una en una colección privada, y una en el Berlin Ethnographical Museum.

15 Por ejemplo, Gallatin proponía que la civilización había surgido en la Costa del Golfo de México y que los mound builders eran resultado de una migración de aquellos pueblos. 
Ninguna de estas interpretaciones tuvo mayor resonancia en el ambiente intelectual: no se iniciaron exploraciones en la región ni se trasladaron las piezas de basalto al Museo Nacional. Sólo algunas de las piezas se integraron a las colecciones nacionales hasta bien entrado el siglo xx, pero no fueron identificadas con ningún pueblo en particular. Su importancia no se basaba en su procedencia cultural, sino en su material de manufactura: el jade. ${ }^{16} \mathrm{Al}$ menos esto se desprende del Catálogo de la colección de objetos de jade elaborado por Ramón Mena. Fue publicado en 1927 para dar a conocer las piezas de jade que guardaba celosamente el Museo Nacional en sus gabinetes. ${ }^{17}$ Las piezas del catálogo, de escultura y lapidaria en su mayoría, estaban fabricadas en jade y procedían de diversas exploraciones. Constituían una "colección" dentro del Museo y, en parte, ello respondía a la importancia que, desde el siglo XIx, se atribuía a tal material entre los pueblos antiguos más importantes de Asia y el Viejo Mundo. ${ }^{18}$

16 SAville, "Votives Axes from Ancient Mexico", pp. 335-342, también identifica tres piezas de jade en el Museo Nacional: una máscara de jade descrita por Mena en su Catálogo de 1927 con el número 1, la placa designada con el número 6 y un hacha. La primera de estas piezas actualmente se exhibe en la sala Culturas de la Costa del Golfo del Museo Nacional de Antropología.

17 Mena, Catálogo.

${ }^{18}$ Las piezas de jade generalmente eran consideradas como amuletos y parte de la cosmogonía de los pueblos. Entre las piezas del Catálogo de la colección de objetos de jade se encontraban, por ejemplo, las encontradas en Monte Albán por Leopoldo Batres a inicios del siglo. El inspector consideraba que todos los amuletos que se habían encontrado en Egipto "[...] se encuentran muy aumentados entre las antiguas tribus de México, que los hicieron también de finísimas piedras preciosas, como son la verdadera esmeralda, la turquesa, las ágatas, la coralina, el cristal de roca, la 
Todas estas piezas adquirieron un nuevo valor dentro del catálogo. Como el mismo Mena aseguraba, hasta hacía pocos años se pensaba que el jade sólo procedía de Asia. ${ }^{19}$ Sin embargo, en 1910 William Niven había localizado un yacimiento en Guerrero, en el río del Oro. Este tipo de vetas se siguieron encontrando en los siguientes años y la importancia de estos hallazgos hizo que el director del Museo, Luis Castillo Ledón, ordenara la realización del catálogo. En la publicación de éste, Mena adjuntó la nota de periódico que fue publicada en relación con el hallazgo de los yacimientos por el periódico Excelsior el 8 de enero de 1927:

LA QUE SE CREÍA ROCA EXCLUSIVA DE CHINA, EL JAPÓN Y LA INDIA, LA HAY TAMBIÉN AQUÍ.- HERMOSOS YACIMIENTOS.MINAS RIQUÍSIMAS HAN SIDO DESCUBIERTAS EN LA BARRANCA DE TOLIMÁN, EN ZIMAPÁN.

El descubrimiento de vetas de jade en México es un acontecimiento en la historia de la mineralogía y de la arqueología de América y se ha logrado después de arduas investigaciones que culminaron con todo éxito [...].

Una gran preocupación de mineralogistas y arqueologistas del Continente americano venía siendo la de que el jade era

ematitis, la serpentina, la turquesa, la obsidiana de cuatro colores, la concha nácar, el hueso, el jade oriental de procedencia asiática que no hay en los terrenos de Europa y les fue desconocido á los Egipcios, y muchas otras piedras que sería difícil enumerar". Véase BATREs, Exploraciones de Monte Albán, p. 24. Actualmente estas piezas se encuentran en exhibición en la sala Culturas de Oaxaca del Museo Nacional de Antropología.

19 El profesor, sin embargo, no perdió oportunidad de sugerir relaciones con Asia. Señala, por ejemplo, que "[...] el nombre actual, JADE pronunciado yéid ¿̇erá relación con la palabra china yú? (pronunciado yi)”. Mena, Catálogo, p. 7. 
absolutamente chino y que su existencia en América se debía a contactos con el Celeste Imperio en épocas remontísimas; pero al formarse el Catálogo de Jades en el Museo Nacional de Arqueología, el profesor de la materia, bien conocido en el mundo americanista, licenciado Ramón Mena, consagró tiempo a estudiar la calidad y procedencia y trabajo de cada pieza, y son casi $600[\ldots]^{20}$

Al parecer, había sido el propio Mena quien solicitó al ingeniero de minas, Rafael de la Cerda, la búsqueda de jade en las minas de Zimapán, Hidalgo. La empresa resultó exitosa al encontrar hilos del mineral entre la pizarra de la Barranca de Tolimán.

En el catálogo el profesor integró los datos de 555 piezas, dos de las cuales pertenecían a colecciones particulares. Además de brindar la descripción general de cada objeto, Mena agregó su procedencia, ya fuera geográfica o cultural. En el primer caso, la mayor parte de las piezas fueron colectadas en Morelos, Guerrero, Oaxaca y el centro de México, lo que coincidía con los yacimientos del mineral que se tenían identificados hasta ese momento. En el segundo, los objetos fueron designados como nahuas o mixtecos.

La apreciación de las piezas manufacturadas en este mineral cambió radicalmente cuando, en 1942, la región de los Tuxtlas se consideró el origen de la historia prehispánica y las piezas se identificaron con la "cultura madre”. Como señalara Wigberto Jiménez Moreno, ese año fue “decisivo” porque el conocimiento alcanzó su culminación al definir la cultura de los olmecas en la Segunda Mesa Redonda

${ }^{20}$ Mena, Catálogo, pp. 76 ss. 
de la Sociedad Mexicana de Antropología. ${ }^{21}$ Luego de haber definido que la Tollan referida por el padre Sahagún en su Historia de las cosas de la Nueva España se encontraba en Teotihuacan (Estado de México) y no en Tula (Hidalgo), ${ }^{22}$ los estudiosos convocaron a una nueva reunión en Tuxtla Gutiérrez. Bajo el título "Mayas y olmecas" discutieron la relación existente entre los restos que había localizado Matthew Stirling, jefe de la Oficina de Etnología Americana de la Smithsonian Institution, en La Venta, y aquellos referidos por las fuentes como olmecas. ${ }^{23}$ Stirling, comisionado por la Smithsonian Institution y el National Geographic, había estado explorando desde 1938, primero en Tres Zapotes, Veracruz y, luego, en La Venta, Tabasco, atraído tanto por la cabeza de Hueyapan como por la idea de encontrar datos relacionados con la Estatuilla de los Tuxtlas,

${ }^{21}$ Fue en la Segunda Reunión de la Sociedad Mexicana de Antropología, celebrada en Tuxtla Gutiérrez, Chiapas, en 1942, cuando se definió que los restos arqueológicos de la región de los Tuxtlas eran una cultura, la "cultura madre", es decir, el origen del resto de las manifestaciones civilizadas del México prehispánico. Véase SMA, Mayas y olmecas.

En 1942, Jiménez Moreno presentó en Cuadernos Americanos un resumen detallado de parte de las discusiones vertidas en esta Mesa, sobre todo, de su propuesta sobre la identificación de los olmecas arqueológicos y los históricos (es decir, los referidos en las fuentes). Véase JimÉNEZ Moreno, "El enigma de los olmecas".

${ }^{22}$ Las discusiones de esta Mesa están en "Conclusiones adoptadas por la Reunión de Mesa Redonda de la Sociedad Mexicana de Antropología”, "Primera Sesión de la Mesa Redonda... Boletínes, 1-4", Archivo Histórico de la Sociedad Mexicana de Antropología, sin catalogación. Algunos de los trabajos fueron publicados en Revista Mexicana de Estudios Antropológicos, t. V, 1941.

${ }^{23}$ Matthew Stirling comenzó a trabajar en Tres Zapotes en 1938 y mantuvo sus exploraciones al menos hasta 1946. Sus reportes de exploración están en Archivo Técnico de Arqueología, B/311.42(S)/22-10, leg. I. 
la cultura maya y los restos de Misisipi. Sus descubrimientos comenzaron a detonar inquietudes entre la comunidad de estudiosos, sobre todo por las numerosas piezas de jade descubiertas (cuando no se habían encontrado yacimientos extensos de este mineral en América) y la llamada estela C, que de acuerdo con la interpretación de Stirling, acusaba la fecha más temprana para toda América: 291 a. C.

Es así que la Segunda Mesa Redonda de la Sociedad Mexicana de Antropología fue destinada a discutir estos hallazgos. Al cabo de la reunión, se decidió hacer una diferenciación entre los olmecas referidos en las fuentes y los restos hallados por Stirling, denominando a estos últimos Cultura de la Venta (para no causar confusiones). Con base en la propuesta de Miguel Covarrubias, Alfonso Caso recomendó a su vez denominarla una "cultura madre", por ser el origen del resto de las manifestaciones culturales del territorio. ${ }^{24}$

En estos momentos también surgieron claros intereses por trasladar al centro del país las esculturas localizadas en la zona, fuesen de jade o no. Poco antes de que se celebrara la reunión de la Segunda Mesa Redonda de la Sociedad Mexicana de Antropología, en la que se definió la "cultura madre", Miguel Covarrubias y Juan Valenzuela fueron comisionados a La Venta para inspeccionar los trabajos que entonces estaba realizando la Smithsonian Institution en la zona. En su reporte, Valenzuela señaló que, pese a que únicamente se pudieron hacer algunas excavaciones menores sin descubrimientos de mayor importancia, estaba claro que el Instituto Nacional de Antropología e Historia debería iniciar lo más pronto posible sus propias exploraciones en

${ }^{24}$ Las discusiones de la Mesa celebrada en 1942 en SMA, Mayas y olmecas. 
la zona y realizar el traslado de las esculturas a la capital, el cual sería "relativamente fácil".

Sugería llevar una de las cabezas mejor conservadas, misma que alcanzaba los $2.5 \mathrm{~m}$ de altura. De acuerdo con su informante, el señor Sánchez, era posible prolongar un canal hasta la tierra firme de la isla y colocar la escultura en un guayín doble que sería arrastrado por un tractor. Estos vehículos eran capaces de arrastrar un guayín hasta con cuatro calderas con un peso de 7 toneladas cada una. Luego, los chalanes podrían hacer llegar la pieza hasta el puerto de Veracruz (presumiblemente arrastrándola por la corriente del río Tonalá), maniobra que tendría que realizarse durante los meses de mayo a junio, tiempo en el que los nortes disminuían. Una vez en el muelle, la escultura podría ser colocada en el ferrocarril. 25

Pese a la facilidad prometida, ninguna pieza fue traslada entonces, aunque al poco tiempo hubo una nueva tentativa. En julio de 1945, Daniel Rubín de la Borbolla fue comisionado para inspeccionar los monumentos de La Venta y evaluar su posible traslado a la ciudad de México. ${ }^{26}$ Durante su expedición, Rubín de la Borbolla tomó las medidas de cada escultura para poder calcular su volumen y peso, y estimó que su traslado a la capital sería fácil pero costoso, y que sería necesario contar con la ayuda de Petróleos Mexicanos, que podría facilitar el equipo, el transporte y los gastos que generarían los trabajos.

25 ATA, Smithsonian reportes, t. CVI, exp. 12. "Informe de una segunda visita a la zona arqueológica de La Venta, del estado de Tabasco", Ms., 8 pp., 18 de abril de 1942.

${ }_{26}$ ATA, Smithsonian reportes, t. CLXXII, exp. 32. "Informe La Venta Tabasco", Ms., 2 pp., 14 de julio de 1945. 
Es posible que el reporte de Rubín de la Borbolla haya sido demasiado optimista, pues como él mismo refiere, la ruta para llegar a la zona requería de varios medios de transporte, así como de numerosas horas de viaje:

La forma más fácil y rápida de hacer el viaje es la siguiente: por carretera de Minatitlán a Coatzacoalcos (cerca de 38k. Petróleos proporcionó camioneta pero hay servicio regular de camiones cada hora); Se cruza el Río Coatzacoalcos en lanchas de servicio público, pasaje $\$ 0.20$. En la rivera Sur del río se toma el tren en la Estación. El tren sale a las 14:00hs. y llega al Plan hacia las 17 hs. De la Estación El Plan al campo petrolero "Las C[h]oapas" en camión unos 15 minutos. De las C[h]oapas en lancha por el Río Tonalá bajando hacia el Este hasta llegar a La Venta (Petróleos proporcionó la lancha PEMEX 352 de 3 pies de calado y 16 millas náuticas) El viaje por el río toma cerca de 3 horas. En el Muelle del Canal de La Venta hay una caseta de teléfonos para comunicarse con el campamento, de este modo se obtiene un camión para llegar al campamento, que está en la loma de la zona, cerca de $3 \mathrm{~km}$ del muelle. ${ }^{27}$

Pese a estos planes, las grandes esculturas de basalto no salieron del estado. ${ }^{28}$ Es posible que las maniobras de traslado dificultaran la tarea, pues los objetos de jade, de menor peso y

27 Sitio actualmente denominado "Las Choapas". ATA, Smithsonian reportes, t. CLXXII, exp. 32. "Informe La Venta Tabasco", Ms., 2 pp., 14 de julio de 1945.

${ }^{28}$ STIRLing, "Discovering”, p. 217, se refiere a que la Estela "C" sí fue trasladada a la ciudad de México luego de su descubrimiento, pero no me fue posible localizar los reportes al respecto. Actualmente, el fragmento inferior de la pieza se encuentra en el Museo Nacional de Antropología, en la sala Culturas de la Costa del Golfo, y el superior en el Museo de Tres Zapotes, Santiago Tuxtla, Veracruz. 
tamaño, sí fueron llevados a la ciudad al poco tiempo de ser descubiertos. ${ }^{29}$ Además de los problemas ocasionados por el tamaño de los grandes monolitos, es posible que existiera cierto conflicto entre los intereses federales y centralistas del Museo Nacional en la capital y los de cada una de las entidades federativas, en torno de la preservación y custodia del patrimonio. ${ }^{30}$ Esta situación ya se había presentado años atrás en el caso de las joyas de la Tumba 7 de Monte Albán y, luego de largos litigios, el estado de Oaxaca logró obtener la custodia de las piezas.

Como fuera, al parecer el Museo Nacional prescindió de las grandes esculturas para la integración de la "cultura madre” en su discurso. Desconozco si existen representaciones gráficas o descripciones de las salas del Museo para las décadas de los años cuarenta y cincuenta, pero me parece posible que las pocas piezas de la "cultura olmeca" que conservaban las colecciones del Museo (como algunas de las descritas en el Catálogo de la colección de objetos de jade) hayan sido integradas junto con las de la cultura arcaica.

29 Por ejemplo, en 1943, se reporta la lista de objetos de jade que fueron entregados al Museo Nacional, mismos que habían sido localizados en las tumbas descubiertas dos años antes. ATA, Smithsonian, leg. 2, s.n.f. "Lista de jades y objetos arqueológicos entregados por el doctor Matthew W. Stirling a este Museo y que proceden de las exploraciones practicadas en La Venta, Municipio de Huimanguillo Edo. de Tabasco, patrocinadas por el Geographic Magazine y el Instituto Smithsonian de Washington, D.C.”, Ms., 7 pp., 29 de mayo de 1943.

30 A partir del siglo xx el concepto de patrimonio comienza a ser utilizado de manera extendida (antes los restos se designan como antigüedades), en buena medida por las discusiones legales sobre la materia, y es posible que también por el creciente interés nacionalista sobre la custodia de los restos. No obstante, este es un tema pendiente de análisis. Es por ello que aquí limito el uso del término a partir de los años treinta. Un análisis sobre el desarrollo de las legislaciones en la materia en Cоттом, Nación, patrimonio cultural y legislación. 
Las cosas cambiaron cuando, durante el sexenio de Adolfo López Mateos se dio una nueva sede al Museo Nacional y se reservó una sala de exposición exclusiva para la "cultura madre". Con la nueva sede, se buscaba brindar instalaciones modernas y adecuadas a todas las colecciones que por varias décadas habían permanecido en la calle Moneda del Centro Histórico. El monumental edificio revestido de mármol se ubicó en el Bosque de Chapultepec, sobre la Avenida Paseo de la Reforma. Para ello, las colecciones existentes resultaban insuficientes, por lo que los investigadores se dieron a la tarea de colectar nuevos ejemplares: se llevaron a cabo 70 expediciones de estudio y el acopio de materiales de etnografía nacional; varias exploraciones arqueológicas en diversos sitios; recuperación de estelas y monolitos de zonas alejadas; y adquisiciones por donación o compra. ${ }^{31}$

Entre los materiales recabados, sin embargo, tampoco se incluyeron las esculturas monumentales olmecas. Parte de las piezas que fueron colectadas en estas misiones pueden conocerse gracias a una publicación especial que se hiciera para celebrar la apertura del Museo. Para la fecha de inauguración del flamante Museo Nacional de Antropología, el 17 de septiembre de 1964, se tiraron 2000 ejemplares de un catálogo en papel couché, que mostraba 130 piezas en fotografías a color, organizadas de acuerdo con la cultura de procedencia, y acompañadas de una breve descripción técnica. ${ }^{32}$ Las piezas arcaicas, entre las que se encontraban las olmecas,

\footnotetext{
${ }^{31}$ La adquisición de piezas de colecciones particulares alcanzó los 3000 ejemplares.

32 Este catálogo sólo presentaba las piezas más representativas que fueron colectadas, por compra o expedición, en una primera etapa. Véase Aveleyra Arroyo de Anda, Obras selectas del arte prehispánico.
} 
eran dos vasijas de barro antropomorfas y una figura femenina de barro de Tlatilco, así como cuatro piezas de filiación olmeca: un vaso que presenta una cara felina esgrafiada ("monstruo olmeca"); una vasija zoomorfa que representaba al "monstruo olmeca"; un fragmento de mascarilla olmeca; y otro de un torso y cabeza de escultura de barro hueca del dios Xipe con rasgos olmecas. ${ }^{33}$

El encargado de las expediciones en el área, así como de la planificación de la sala fue Román Piña Chan. Para la elaboración de esta última proponía mostrar "el problema olmeca" abordando varios tópicos en su descripción, que abarcaran desde las hipótesis sobre la cultura y la ecología de su medio, hasta sus rasgos sociales básicos, como la economía, indumentaria y adorno, tecnología, vivienda, organización socioeconómica, conocimientos y estética.

La descripción de la cultura como "problema" se debía fundamentalmente a dos razones: por un lado, era preciso distinguir estos restos arqueológicos de la cultura "olmeca" denominada así por las fuentes históricas ${ }^{34} \mathrm{y}$, por otro lado, destacar su extensa presencia en el territorio y lo poco que se conocían las razones de este fenómeno. La magna publicación sobre historia prehispánica que apareció pocos años antes de la inauguración del Museo Nacional, y con

33 Sólo las dos últimas fueron colectadas en Veracruz (en El Ocotal y El Faisán), mientras que las otras cinco las donaron George Pepper y su esposa.

34 Tal distinción fue propuesta por Jiménez Moreno desde la Mesa que se celebrara en 1942. En el mismo sentido, Alfonso Caso propuso denominar los restos arqueológicos de esta cultura "cultura de La Venta". No obstante, estas propuestas no prosperaron y en general se usó "olmeca" para denominar los restos arqueológicos. 
la cual se buscaba rectificar las imprecisiones sobre nuestros pueblos nativos de su antecesora México a través de los siglos, Esplendor del México antigno, afirmaba que esta cultura, la de los "tecolenome" (como propone denominarlos Wigberto Jiménez Moreno para no confundirlos con los “olmecas históricos”), se ubicaba en el Preclásico Medio, como parte de los motores que provocaron las incipientes urbanización de villas y estratificación social, y con gran presencia en los pueblos de la cuenca de México.

Sin embargo, y pese a la intención de los autores de impulsar la reflexión sobre un "problema", se percibe la convicción de vincular este desarrollo con un único origen. Su fuerte presencia en varios puntos del territorio es para Jiménez Moreno una poderosa razón que lo vincula con los gérmenes que dieron cabida a la unidad mesoamericana, ${ }^{35}$ mientras que Ignacio Bernal señala que la cultura olmeca fue el "primer gran arte de Mesoamérica”, un área que por antonomasia representaba la unidad de origen común a todas las culturas. ${ }^{36}$

En esta misma tónica, Ignacio Bernal publicará El mundo olmeca en 1968, como el primero de una serie de libros que

35 Jiménez Moreno, “Síntesis de la historia”, t. II, pp. 1019-1039.

36 BERNAL, "Evolución y alcance de las culturas mesoamericanas", p. 97. No obstante, la persistencia de observar lo olmeca arqueológico como el gérmen de un solo desarrollo (mesoamericano, civilizado, etc.), la obra en la que se insertan estos trabajos, Esplendor del México antiguo, marca en general una nueva transición en la escritura de la historia prehispánica. Entre otras cosas muestra la reinserción de la prehistoria como problema. Véase el capítulo de Aveleyra Arroyo de Anda, "Los cazadores del mamut,", los debates sobre el origen de la agricultura con base en exploraciones en el territorio nacional. Véase también el capítulo de MiLlón, "La agricultura como inicio de la civilización", y la introducción de una periodización más refinada que incluye el Epiclásico. 
integrarían toda la historia de Mesoamérica, desde sus "inicios como mundo civilizado”. Aquí, Bernal asegura que

En un momento dado y en un área precisa, pueblos aldeanos que no son sino el antecedente de la historia que deseamos rela$\operatorname{tar}$ [la mesoamericana], inician su diferenciación y el paso que los llevará a la civilización. La época es el fin del segundo milenio antes de Cristo y el área la región del sur de Veracruz. Más tarde surgirá allí, hacia el año 800 antes de nuestra era, la civilización olmeca y con ella lo que será la civilización Mesoamericana. $^{37}$

De la misma forma, el arqueólogo campechano Román Piña Chan destacaba en el Museo Nacional que la cultura olmeca no era primitiva en ningún sentido, sino que, por el contrario, “[...] alcanzó desde El Opeño hasta El Salvador; fue factor importante en el desarrollo de culturas como la Maya, Totonaca y Teotihuacana; a la vez que dio nacimiento a la Zapoteca, que floreció en la región Oaxaqueña. Por esta razón se le ha llamado una cultura madre". ${ }^{38}$

Esta afirmación estaba en absoluta consonancia con el objeto del nuevo edificio del Museo, porque atrás estaba la

37 Bernal, El mundo olmeca, p. 13. Este argumento, sobre los olmecas como el origen de la civilización, es el fundamento de Bernal para asegurar que la arqueología en México es, fundamentalmente, historia, y no antropología, porque estudiaba civilizaciones y no los pueblos primitivos. Véanse en p. 6.

38 Román Piña Chan, "Guión de la Sala de la cultura olmeca. Planeación e instalación del Museo Nacional de Antropología”, Ms. INAH-CAPFCE, 29 de junio de 1961, pp. 2 y 20. Agradezco profundamente la gentileza de la doctora Beatriz Barba, quien hace ya varios años me facilitó el material utilizado para la planeación del Museo Nacional en 1961. Al ser parte de su archivo personal, este material no tiene clasificación. 
“[...] época en la cual, en museos y galerías del extranjero, [al arte prehispánico] se le almacenaba junto con antiguallas y curiosidades etnográficas de los llamados pueblos primitivos". Los restos precolombinos, ahora se reconocía plenamente, eran parte de las "[...] creaciones destacadas de las grandes civilizaciones de la antigüedad" y, como tales, merecían un lugar privilegiado. ${ }^{39}$

Algunos autores han destacado que la apertura del Museo Nacional de Antropología fue la continuación del proyecto de legitimización de la hegemonía modernizadora, con el que los bienes históricos y tradicionales pasaron a formar parte de una narrativa general y común. ${ }^{40}$ El Museo Nacional de Antropología, como un escenario, representa, a la vez que ritualiza, el patrimonialismo mexicano, histórico y antropológico, desde su más remoto origen.

En tal escenografía, el discurso museográfico iniciaba con los primeros pobladores mexicanos y acentuaba el surgimiento de las grandes culturas, entre las que se encontraba la olmeca. La inclusión de las antes consideradas culturas "primitivas", sin embargo, no transformó la universalidad de la historia construida en el siglo XIx. El recorrido propuesto para el visitante al nuevo Museo iniciaba en el ala derecha del edificio, para luego de traspasar la sala introductoria de antropología, recorrer el sendero de la civilización, desde la "cultura madre" hasta encontrarse, al fondo del recinto, con la Piedra del Sol, que mantenía su lugar privilegiado como la máxima creación de la antigüedad prehispánica. ${ }^{41}$

39 Aveleyra Arroyo de Anda, "Presentación", Obras selectas del arte, sin número de página.

40 Véase por ejemplo García Canclini, Culturas hibridas, p. 151.

41 En una lectura un tanto diferente, García CANCLINI, Culturas híbridas, 
En los últimos años, no obstante, el lugar museográfico de la cultura olmeca fue modificado. Durante la remodelación del Museo Nacional, la llamada "cultura madre" fue desplazada del lugar originario que ocupaba, a otro de menor importancia en relación con las culturas del centro del país. Actualmente, al recorrer sus salas, el visitante atento puede observar la influencia olmeca en diversas culturas, como la del Preclásico del Altiplano o en las culturas de Oaxaca. Pero lo "olmeca" ya no se encuentra al inicio del recorrido. Este lugar lo ocupa la sala del poblamiento de América, y es seguido de los desarrollos de la cuenca de México (desde el Preclásico hasta el Posclásico). ${ }^{42}$

Sólo luego del desarrollo mexica y de las culturas de Oaxaca, el visitante accede por medio de un pasillo a la sala de las Culturas de la Costa del Golfo, como un mero preludio del esplendor maya. Aquí se pueden observar diversas esculturas monolíticas y de jade, así como algunas piezas

p. 173, considera que la propuesta museográfica de recorrido tiene dos sentidos: el inicio por el ala derecha, que recorre los fundamentos de la ciencia antropológica y desemboca en las culturas áridas del norte; o bien, el inicio contrario, por el ala izquierda, que concluye con el fundamento científico. En cualquiera de ambas, el centro de las salas y del discurso lo constituye la sala Mexica, que representa la "unificación establecida por el nacionalismo político en el México contemporáneo" y la "sede del poder”. Una interpretación similar que, además, aborda el interés histórico del Museo por constituirse en el recinto del discurso nacional, en Frida Gorbach, "El Museo Nacional: visita a un monumento", Ms., 55 pp., mayo de 1995, proporcionado por la autora.

${ }^{42} \mathrm{El}$ orden de las salas es el siguiente (de derecha a izquierda): Culturas Indígenas de México; Introducción a la Antropología; Poblamiento de América; Preclásico en el Altiplano Central; Teotihuacán; Los Toltecas y su época; Mexica; Culturas de Oaxaca; Culturas de la Costa del Golfo; Maya; Culturas de Occidente; y Culturas del Norte. 
cerámicas en nada comparables a las de las salas anteriores. ${ }^{43}$ En este espacio, lo “olmeca” ya no es designado con el nombre de la "cultura madre", sino como:

[...] la primera civilización mesoamericana con características originales como centros arquitectónicos planificados -La Venta, Tabasco, Tres Zapotes, San Lorenzo y Veracruz-, religión compleja y estructurada.

Las primeras esculturas monumentales en piedra y pequeñas figuras en piedra verde; organización social y política con una clara jerarquización; agricultura intensiva; inicio de la escritura y del calendario; técnicas de construcción tanto arquitectónica como escultórica, y el establecimiento de rutas comerciales. ${ }^{44}$

Los acuerdos de la Segunda Mesa Redonda en 1942 son así retomados sólo parcialmente y la presencia de lo "olmeca” se diluye en el discurso que presenta el Museo. Al tiempo, el centralismo de la narrativa se mantiene: como antaño, como siempre, el centro del recinto sigue ocupado por la cultura mexica. Desde el umbral de la puerta central del recinto, los ojos del visitante quedan presos ante la grandeza de la Piedra del Sol que, elevada al fondo de la sala, corona todo el espacio y la historia. ${ }^{45}$

43 Entre las piezas monumentales se encuentran dos cabezas colosales (monumentos 2 y 17) provenientes de San Lorenzo, así como réplicas de la Estatuilla de los Tuxtlas, de la cabeza de Hueyapan y de la tumba de Columnas de basalto encontrada por Stirling en La Venta.

44 Cédula museográfica, sala Culturas de la Costa del Golfo, Museo Nacional de Antropología.

${ }^{45}$ Debajo de esta pieza se encuentra la fotografía que se tomara Porfirio Díaz al lado de la Piedra del Sol. Ello no deja de constituir un detalle revelador del centralismo y presidencialismo que supera, incluso, las tendencias antiporfiristas de nuestra historia patria oficial. 
En buena medida, la revaloración de las piezas olmecas y su inclusión en la historia nacional alrededor de la primera mitad del siglo xx respondió a los cambios ocurridos en la apreciación universal sobre lo primitivo. Para el momento en que el National Geographic Magazine publicaba los resultados de las exploraciones de Matthew Stirling en Tabasco y Veracruz, y se llevaban a cabo las reuniones de la Segunda Mesa Redonda, el mundo entero participaba de una transformación en la apreciación estética del arte que influyó no sólo en la revaloración de las piezas olmecas, sino en todo el espectro de lo prehispánico.

Los intelectuales mexicanos, al menos desde la segunda mitad del siglo xIx, se habían cuestionado acerca de la calidad artística de los restos prehispánicos y, a la vuelta del siglo, aún no existía un consenso sobre el tema. No obstante, el nuevo siglo, la desconfiguración de Occidente tras la Gran Guerra y el rechazo a los valores de evolución y progreso del siglo xix, la institucionalización de la antropología relativista y las nuevas miradas desde la estética, trajeron consigo nuevos parámetros que modificaron el ideal de universalidad.

Con la apreciación de las realidades americanas, africanas y de Oceanía se modificó el valor asignado al pasado y presente no occidentales. A partir de las expediciones antropológicas francesas al continente negro y de la búsqueda de "culturas" (en plural) propiciada por la nueva subjetividad etnográfica impulsada por Bronislaw Malinowski y Franz Boas, los objetos no occidentales (exóticos) comenzaron a considerarse como piezas únicas que, más allá de su valía 
histórica como parte de la vida social cotidiana, poseían elementos estéticos dignos de admiración y de reconocimiento universal. Lo exótico se convirtió entonces en la afrenta directa a la racionalidad, a la belleza y a la normalidad de Occidente.

Al tiempo, las nuevas propuestas artísticas pugnaron por elevar las nociones antes rechazadas por el romanticismo pictórico, enalteciendo la cotidianidad, la vulgaridad, lo común, lo grotesco, la fealdad. En este proceso, las piezas arqueológicas americanas transitaron por una revaloración en la mirada occidental, al menos, desde la década de los años veinte, cuando además de ser apreciadas por su grado de civilización, fueron admiradas como "piezas de arte", propiciando con ello una resignificación del patrimonio arqueológico. ${ }^{46}$

${ }^{46}$ Un análisis sumamente interesante sobre los cambios ocurridos en el arte y la antropología a partir de los años veinte, en Clifford, Dilemas de la cultura. De acuerdo con este autor, este cambio de apreciación puede observarse claramente en la primera exhibición de arte precolombino en Francia, encabezada por Georges-Henri Rivière antes de la apertura del Musée de l’Homme en 1937.

Para BArtra, El salvaje artificial, cap. IX y Epílogo, la evolución del primitivismo en el arte europeo moderno constituye una resignificación más del mito del salvaje. Como un rechazo a Occidente, se buscó la ruta de escape hacia el pasado, la infancia, la locura o el mundo onírico. "El mundo primitivo se hallaba en el interior y no en el exterior de la cultura occidental; y el arte primitivista moderno aparecía como una búsqueda de la simplicidad y, sobre todo, de la totalidad no fragmentada del hombre" (p. 235).

НовSвашм, Historia del siglo XX, cap. VI, brinda también un erudito análisis sobre la reconfiguración de las artes en el espacio entre guerras, que anunció "con varios años de anticipación el hundimiento de la sociedad burguesa liberal” (p. 182). 
En México, a partir de la segunda década del siglo, parece impulsarse la valoración de la "estética prehispánica" para rechazar los parámetros occidentales. Por ejemplo, en Forjando patria, Manuel Gamio escribía que, pese a que no era común aceptarlo, la calidad artística se había desarrollado en todas las latitudes y en todos los tiempos históricos. Sin embargo, aducía Gamio, la sociedad occidental partía de los parámetros clásicos de Occidente para establecer sus juicios estéticos y las obras que generalmente eran aceptadas como arte eran aquellas que "[...] despiertan emoción estética en los observadores, por su semejanza morfológica, que en casos llega a ser identidad, con las representaciones del arte occidental, arte que les es familiar, que están habituados a juzgar, a estimar, a producir y a sentir". ${ }^{47}$

Gamio consideraba que estas valoraciones eran erróneas porque partían del desconocimiento absoluto de las culturas productoras del arte. Para poder apreciar cada una de estas manifestaciones y lograr una comprensión verdadera y legítima, era indispensable la correcta ubicación y el entendimiento de los parámetros históricos, sociales y artísticos de cada pueblo. Sólo de esta manera se podría encontrar la armonía entre la belleza de la forma material y la comprensión de la idea que expresaba cada pieza. En sociedades como la mexicana, lamentablemente, existía un fuerte desconocimiento sobre el pasado precolombino que dificultaba su correcta valoración estética.

\footnotetext{
47 Gamio, Forjando patria, p. 44. Para Ovando Shelley, "Arte precolombino”, pp. 148-149, las apreciaciones de Gamio, aun cuando no logran abandonar del todo el positivismo, recuperan la visión espiritualista y esencialista de la historia introducida en México por los miembros del Ateneo.
} 
De manera general estas apreciaciones fueron integrándose paulatinamente en la revaloración del pasado prehispánico y, para cuando se discutió el lugar y el valor de la cultura olmeca en la historia prehispánica, ya constituían una base de aceptación común para el medio arqueológico. ${ }^{48}$

No obstante, la generalización y aceptación de estas propuestas no fue un proceso inmediato, sencillo ni natural. Mucho antes de que se propusieran la existencia de una "cultura madre", parte de los estudiosos mexicanos sujetaron a las culturas más representativas del pasado prehispánico a la medición de los nuevos parámetros estéticos y, sobre todo, promovieron su nueva imagen, como verdaderas obras de arte, ante la comunidad nacional e internacional.

Quizá una de las primeras muestras la constituya la exposición en diversas exhibiciones nacionales e internacionales de las joyas procedentes de la Tumba 7 de Monte Albán. Luego de su descubrimiento en 1932, y de que éste fuera notificado a los medios académicos nacionales e internacionales, la noticia cundió como pólvora. Este mismo año se hizo una exhibición de las joyas en Oaxaca, para luego trasladar la colección a la ciudad de México.

El año siguiente (1933), en ocasión de la feria mundial llevada a cabo en Chicago, se montó una exposición con las joyas. La feria, "A Century of Progress", tenía como objeto conmemorar el centenario de la ciudad y mostrar los logros

${ }_{48}$ No pretendo sugerir que Manuel Gamio haya sido el generador de tales propuestas. Como se verá en adelante, fueron varios los autores que, al menos desde al ámbito arqueológico, hicieron propuestas similares. Por otro lado, los cambios en la apreciación artística también estuvieron acompañados de modificaciones en el discurso histórico y en la construcción de los objetos epistémicos. 
científicos e industriales de este momento. Se montó sobre dos lagunas artificiales en Northerly Island, a la orilla del lago Michigan, al sur del Navy Pier. Se abrió al público del 27 de mayo al 12 de noviembre de 1933 y, posteriormente del $1^{\circ}$ de junio al 31 de octubre del año siguiente. ${ }^{49}$

En las 112 ha que ocupó, México presentó una reconstrucción de un templo maya y la exposición de las joyas de Monte Albán. La elección de estos sitios no fue casual en absoluto. De todas las excavaciones realizadas en los últimos lustros, sólo las realizadas en el sureste y en Oaxaca podían igualar la fama que alcanzaron años atrás las ruinas de la "ciudad de los dioses". ${ }^{50}$ De esta forma, los sitios llevados al extranjero mostraban los puntos de origen civilizatorio más remotos que el ego nacional podía exhibir y presumir para estas fechas.

Se realizó así una réplica de parte del Cuadrángulo de las Monjas de Uxmal y también se llevó la colección de Monte Albán que, sin lugar a dudas, era impresionante. Se trataba de más de 300 objetos manufacturados en oro, jade, plata, cobre y concha, valuados en 212346 pesos. ${ }^{51}$ El mensaje

49 Ganz, The 1933 Chicago World's Fair, cap. 7.

${ }^{50}$ De hecho, las ruinas mayas ya habían sido mostradas como imagen del pasado mexicano en varias de las exposiciones universales celebradas con anterioridad. Las exploraciones llevadas a cabo en el sureste, principalmente por extranjeros, habían sido difundidas desde sus primeros momentos, enfatizando la grandeza de la civilización que la creó y constituyendo un tema central en la discusión sobre el pasado de América en general.

${ }^{51}$ Es posible que esta cantidad haya sido estimada para trasladar las piezas al extranjero.

En el salón que previamente había sido destinado para la exhibición de la colección en el Museo Nacional de la Ciudad de México, el 10 de junio de 1933, se reunió la comisión designada para verificar el embalaje de 
resultaba claro: no se estaban presentando objetos etnográficos (propios de la vida cotidiana de los pueblos primitivos), sino verdaderas joyas, es decir, tesoros excepcionales que mostraban el refinamiento, la elegancia y la alta cultura de una de las civilizaciones más importantes del desarrollo de la historia precolombina.

Para mostrar este tesoro, se escogió una estrategia muy diferente a las antes ensayadas, que se encontraba enfocada a mostrar la modernización del país de la mano de su majestuosa historia. Para ello, las joyas fueron exhibidas en el tren presidencial:

The new Republic of Mexico provided another by dispatching its presidential train carrying recently excavated jewels from Monte Alban, Oaxaca. The intent was to announce the republic as a scientifically progressive and economically successful nation. Positioned in the outdoor railroad exhibit near the Travel and Transport Building, the train promoted tourism by trail to Mexico's many historical sites. The palatial coaches, built by Chicago' Pullman Company, advanced the image of a modern industrial state linked by the latest rail network technology; the jewels of gold, silver, jade, turquoise, and pearl on display hinted of the treasures to be found to the south..$^{52}$

las piezas que serían trasladas a Chicago: Ignacio Marquina, director de Monumentos Prehispánicos; Jorge Enciso, director de Monumentos Coloniales; José R. Benítez, investigador de Monumentos Coloniales; y Enrique Juan Palacios, arqueólogo de Monumentos Prehispánicos. Se cotejaron más de 300 piezas con la lista que ofrecía el catálogo realizado para tal efecto. IIA-UNAM, $A C A$, c. 5, exp. 1, s.n.f. "Inventario de la colección de las joyas de la Tumba 7 de monte Albán, Oax. (Exploraciones 1932)", y "Catálogo de las joyas de Monte Albán, 1933".

52 Ganz, The 1933 Chicago World's Fair, p. 132. 
Seguramente por el éxito alcanzado, tras la exhibición en Chicago, las piezas de nuevo fueron trasladadas para otra muestra, esta vez en la feria de San Diego, California. En esta ciudad, en 1935 y 1936, se realizó nuevamente una feria mundial con la intención de impulsar la economía en tiempos de depresión. ${ }^{53}$

Las estrategias discursivas utilizadas cayeron en terreno fértil, pues el mundo arqueológico se encontraba plenamente receptivo para aceptar (al menos hasta cierto punto) la grandeza de los centros de civilización prehispánica. Una vez finalizadas las exposiciones, el Museo Nacional publicó las opiniones de diversas personalidades que observaron la muestra. La mayor parte de estos personajes expresaron su fascinación ante los "tesoros” de Monte Albán y su reconocimiento frente a la grandeza de la civilización que los creó. Hermann Beyer, entonces investigador de la Tulane University, señalaba que "El tesoro de Monte Albán prueba que el historiador Prescott no exageró en su descripción de la suntuosa corte de Moctezuma, como lo han querido demostrar

${ }^{53}$ http://www.balboapark.org/es/en-el-parque, consulta electrónica realizada el 3 de junio de 2009. En México, nuevamente, en el salón del Museo Nacional destinado a la exhibición de las joyas, el 7 de junio de 1935, se reunió la comisión encargada de verificar las piezas que se expondrían: Luis Castillo Ledón, director del Museo Nacional; José de J. Núñez y Domínguez, secretario del Museo; y Miguel Othón de Mendizábal, jefe del Departamento de Arqueología del Museo. También verificaron la operación Eduardo Noguera, Eulogio R. Valdivieso y Agustín Villa Gordoa, quienes serían los encargados de llevar las joyas a la feria. En esta ocasión, únicamente se llevaron 40 piezas que serían exhibidas en cuatro vitrinas con soportes de terciopelo. Véase IIA-UNAM, $A C A$, c. 5, exp. 1, s.n.f. "Inventario de los objetos procedentes de la Tumba 7 de Monte Albán, Oax., que se destinan para ser exhibidos en la exposición de San Diego, Cal.”, mecanuscrito, 4 fojas. 
algunos etnólogos y sociólogos. Los hechos valen más que los argumentos".$^{54}$ Opiniones similares tuvieron personajes como John Merrian, presidente de la Carnegie Institution; J. C. Simms, director del Museo de Historia Natural de Chicago; W. E. Hopper; Wm. Duncan Strong del Bureau of American Ethnology, y Herbert Spinden, arqueólogo del Museo de Brooklyn, además de personalidades mexicanas como Diego Rivera. ${ }^{55}$

El largo trecho recorrido por los eruditos del siglo XIX, sin lugar a dudas, estaba rindiendo frutos, pues el nivel "civilizatorio" de las culturas precolombinas difícilmente podía cuestionarse y, en este sentido, la calidad artística, como nuevo juicio de valor, reafirmaba la importancia del pasado prehispánico. ${ }^{56} \mathrm{Al}$ tiempo, una nueva legislación en dicha materia sería fraguada y, con ello, el valor del patrimonio arqueológico mexicano quedaría expuesto de forma legal con mayor firmeza. ${ }^{57}$

La publicación de las opiniones de tales personajes, autoridades en el medio antropológico y artístico a nivel internacional, por otro lado, muestra el interés de la comunidad mexicana por fundamentar y certificar la nueva percepción sobre el pasado y por difundirla. A esta estrategia también

\section{${ }^{54}$ Opiniones, p. 9.}

55 Opiniones, pp. 5, 9, 16-17.

56 Un análisis sumamente interesante y con relación a la participación de México en las exposiciones internacionales en Tenorio, Artilugios.

57 En 1934 fue sustiuida la legislación de 1895 por una ley más precisa y contundente en cuanto a la protección del patrimonio arqueológico. Es curioso observar cómo la protección legal del patrimonio se torna más precisa y fuerte conforme la valoración estética e histórica de las piezas va en aumento. Para el desarrollo de la transformación de la protección del patrimonio véase Cоттом, Nación, patrimonio cultural y legislación. 
respondió una publicación realizada poco después de las muestras internacionales, destinada a exhibir algunas de las mejores piezas del "arte prehispánico". Fue escrita por Alfonso Caso y presentada en un formato de $28.5 \mathrm{~cm}$ por $20.5 \mathrm{~cm}$, en papel couché, con la descripción detallada de 11 piezas que se encontraban en el Museo Nacional y dos procedentes de Monte Albán, localizadas en el Museo de Oaxaca. La descripción de cada pieza se acompañaba de una fotografía en color.

El título indicaba con claridad el contenido de la obra: Thirteen Masterpieces of Mexican Archaeology. En primer lugar se presentó el Calendario Azteca, y fue seguido de tres esculturas más de la misma cultura: la Coyolxauhqui, Xochipilli y el Caballero Águila. Aparece luego un vaso de jade encontrado en el Estado de México; otro de tecali adquirido por el Museo desde 1827, procedente de la zona totonaca; una vasija de obsidiana de Texcoco y una mixteca; una palma totonaca; una figurilla maya obtenida por el Museo en 1934; un escudo con mosaico de turquesas extraído del interior de la pirámide del Castillo de Chichén Itzá; y dos piezas de oro procedentes de la Tumba 7: el pectoral y la máscara de oro.

El texto que acompañaba a estas imágenes se presentaba en inglés, como una atención al público extranjero al que estaba dirigida la obra, y como una muestra preferencial al sector del mundo que entonces estaba encumbrándose en la cima del mundo. Además, en una segunda parte, se presentaba la traducción al castellano, la cual fue realizada por Jorge Acosta y revisada por George Vaillant. ${ }^{58}$

${ }^{58}$ Caso, Thirteen Masterpieces of Mexican Archaeology, p. 85. 
En Thirteen Masterpieces of Mexican Archaeology, Caso enfatizaba el error que implicaba seguir considerando las piezas prehispánicas, como muchos habían hecho, como figuras simbólicas decorativas o como objetos de terribles significados. Advertía al lector que la mayor parte de las obras "de arte indígena" estaban inspiradas en el sentimiento religioso del pueblo. Para entender estas piezas era menester conocer su significado, porque:

Aun cuando la obra de arte tiene un valor estético independiente del simbolismo que encierra, es indudable que no podremos gustar plenamente de ella si no estamos compenetrados de la idea que inspiró su creación porque el artista, que es plásticamente libre al pensar su obra, está sin embargo, condicionado cuando expresa al través de su temperamento, ideas y sentimientos colectivos, formas sociales de pensar y sentir.

En presencia de un arte exótico, para un hombre de cultura europea, se corre el riesgo de quedar limitado puramente al goce sensible de la forma, el color o el ritmo, pero incapacitado para gustar intelectualmente de la obra de arte y, como no podemos sentir, sin atribuir una intención a lo que sentimos, llenamos con nuestras propias ideas la incomprensión de lo que el artista quiso expresar y, como decía Leonardo de Vinci, nos sucede lo que con la música de las campanas: que dice lo que a cada quien le parece decir. ${ }^{59}$

$\mathrm{Al}$ tiempo en que estas muestras intentaban convencer al público no especializado sobre la calidad artística del pasado precolombino, los especialistas se enfocaron en el armado del edificio argumentativo para sostener tales criterios. La

${ }^{59}$ Caso, Thirteen masterpieces of Mexican Archaeology, p. 85. 
Sociedad Mexicana de Antropología hizo patente su interés por integrar aquel discurso en el seno de sus discusiones y, al celebrarse la Segunda Mesa Redonda en 1942, en la que se definió la "cultura madre", fueron invitados dos miembros de la comunidad artística: Salvador Toscano y Miguel Covarrubias.

El arte maya o el de Monte Albán y Teotihuacán ya habían sido acordados, pero ahora, la definición del origen requería también una fundamentación estética. ${ }^{60}$ Lo olmeca no era bello, ni sensual, ni barroco, ni ordenado, ni florido. Por el contrario, era simple, monstruoso quizá, primitivo o bárbaro, pero -los arqueólogos sabían que- era civilizado y, por tanto, también era artístico.

Durante la Mesa fue Covarrubias quien se encargó de la fundamentación, utilizando la sencillez como un valor estético. El pintor aseguró que:

El arte olmeca es fuerte y simple, pero sabio y vehemente, [...] no tiene nada del sensualismo necrófilo azteca, ni relaciones con el simbolismo flamboyant de los mayas, o con el arte ordenado y florido del Teotihuacán de fin de época. Tampoco tiene relación con el simplismo candoroso y burdo del arte llamado "tarasco". Pero sí está conectado, lejana pero palpablemente, con el arte teotihuacano más antiguo, con el estilo llamado “totonaco", con las formas más viejas del arte maya y con los objetos zapotecas, los cuales mientras más antiguos tienden a ser más “olmecas”. ${ }^{61}$

60 Cabe destacar que ésta fue la única mesa redonda a la que se convocaron personalidades del medio artístico, al menos en las primeras celebraciones llevadas a cabo.

61 Covarrubias, “Origen y desarrollo del estilo artístico 'olmeca'”, p. 46. Años después, el pintor reafirmaría su postura general, al señalar: "Nues- 
Toscano, por el contrario, sólo participó en la discusión general sobre la antigüedad de los restos..$^{62} \mathrm{Al}$ poco tiempo, sin embargo, tuvo que ahondar en sus impresiones, porque el recién fundado Instituto de Investigaciones Estéticas de la Universidad Nacional Autónoma de México impulsó la publicación de obras que intentaban abarcar todo el espectro del arte mexicano, y Toscano fue invitado a colaborar en la primera de éstas, la correspondiente al arte de la época prehispánica. ${ }^{63}$ Arte precolombino de México y de la América Central, publicado en 1944, fue quizá una de las obras que representó mayores problemas, ${ }^{64}$ porque si bien las experiencias anteriores ya habían sentado cierto precedente, el discurso aún no estaba plenamente aceptado entre toda la comunidad de estudiosos, y no resultaba sencillo integrar en éste a todo el espectro del pasado prehispánico, por lo que Toscano se dio a la tarea de justificar una serie de argumentaciones desde el punto de vista científico, histórico y estético ${ }^{65}$ Explicaba al inicio de su obra:

tro conocimiento de las culturas antiguas de estos pueblos está creciendo constantemente, a la vez que los valores modernos del arte nos han ayudado a comprender mejor un arte que, hasta recientemente, habíamos desconocido y menospreciado. Actualmente discernimos valores universales y eternos de arte en nuestras culturas indígenas, las cuales han sido elevadas a un nivel relativo de importancia frente a las de los egipcios, griegos e indios orientales, como parte de nuestro legado artístico universal”. Covarrubias, El sur de México, pp. 21-22.

${ }^{62}$ SMA, Mayas y olmecas, pp. 41-42.

${ }^{63}$ La segunda de las obras, sobre el arte virreinal, fue encomendada a Manuel Toussaint, y la de arte contemporáneo, a Justino Fernández.

${ }^{64}$ Véase el análisis de esta obra desde la historia del arte en Ovando Shelley, "Arte precolombino", en Trejo y Matute (eds.), Escribir la bistoria en el siglo XX, p. 158.

${ }^{65}$ Ovando, “Arte precolombino”, p. 145, considera que Toscano “[...] se 
El estilo artístico es la fisonomía, la forma por la cual se expresa una cultura, su expresión psicológica peculiar; no existe, por lo mismo, un criterio de validez universal que nos permita juzgar el arte de los diversos pueblos en su desarrollo histórico, pues ni siquiera el ideal clásico de los griegos -tradicionalmente señalado como el momento más alto de la humanidad en el arte- puede reclamar tal título. No existen artes bárbaras o inferiores, pues los estilos artísticos no son mejores ni peores, sino diferentes: son el resultado o 'dirección' -dice Worringerde una voluntad artística. ${ }^{66}$

En la obra, Toscano lleva al extremo lo antes considerado por Gamio, al asegurar que el desdén hacia el arte indígena era producto de un hispanismo mal entendido, que erróneamente había juzgado el pasado a partir de criterios occidentales y sin reconocer a tales pueblos. La belleza, de acuerdo con su juicio, no era el único criterio para el arte. También lo terrible era arte:

En la cultura arcaica, una cultura primitiva que se encuentra en los estratos más antiguos de las culturas teotihuacana, zapoteca o maya, el carácter predominante es su nota tremenda. La vía emocional a que recurre el artesano arcaico es a la de lo monstruoso y no pocas veces a lo siniestro; tomemos al azar sus idolillos o penates tan terriblemente enérgicos y evocadores. Más de una vez el juego de luces y de sombras acentúa vigorosa-

enfrentó al problema de volver inteligible a un amplio público las expresiones artísticas del México antiguo, lo que en última instancia implicaba la difícil tarea de fundamentar la existencia de la belleza de éstas". Si bien el objeto de las obras era alcanzar a un público no necesariamente especializado, la narrativa usada por Toscano estaba dirigida a sus pares.

${ }_{66}$ Toscano, Arte precolombino de México, p. 13. 
mente los rasgos de fiereza de la más primitiva estatuaria y súbitamente, con arrebato, se nos presentan los ídolos arcaizantes con su fuerza tremenda envolviéndonos en un ambiente mágico lleno de misterios casi brujescos. ${ }^{67}$

La belleza de los objetos, señalaba, tenía que comprenderse de acuerdo con su nivel evolutivo, pues cuanto más primitivas eran las culturas, su vida y arte se encontraban bajo un dominio religioso mayor. Tanto las esculturas de los Cristos ensangrentados del siglo Xvi, como las piezas aztecas que emulaban el sacrificio, eran obras que sumían al observador en una "embriaguez demoniaca" y le despertaban sentimientos de solemnidad, grandeza y fascinación, en una comunión entre la repulsión y la atracción.

Cualquier ídolo arcaico nos produce un sentimiento negativo -nacido de un asco profundo de esencia religiosa-, pero por otra parte este sentimiento se subordina a otro nuevo, una atracción fascinante: queremos no mirar y clavamos terriblemente nuestra mirada expresando los caracteres profundos de aquel arte. ${ }^{68}$

El arte indígena, decía el autor, como cualquier otro del mundo, había transitado por un proceso evolutivo. Siguiendo al filósofo alemán Oswald Spengler (1880-1936), Toscano consideraba la evolución de los estilos artísticos como el proceso de un ser vivo (y de la sociedad misma) que nace y

67 Toscano, Arte precolombino de México, p. 15. Toscano usa aquí como sinónimos "arte indígena" y "arte prehispánico". Esto no es una particularidad de este autor, sino una tendencia general en el medio, que acusa una transformación en la apreciación sobre el pasado precolonial y su liga con el llamado "problema indígena".

${ }^{68}$ Toscano, Arte precolombino de México, p. 16. 
se desarrolla hasta alcanzar su clímax para luego fenecer. De esta forma, proponía que los estilos prehispánicos transitaban de lo terrible a lo sublime, y de éste a lo bello, para culminar en el barroco.

Sobre lo olmeca, Toscano no integró la "sencillez" propuesta antes por Covarrubias. Por el contrario, consideraba que los restos cerámicos de la cultura arcaica no presentaban mayor relevancia, salvo por las figurillas de cerámica que, sin embargo, eran toscas, bárbaras, sin pulimento ni pintura, trabajadas por pastillaje o torpes incisiones. Reconocía que los restos del área de Veracruz y Tabasco habían sido relacionados con un estadio evolutivo avanzado, pero consideraba que la:

[...] arquitectura de La Venta [...] es sumamente primitiva: montículos piramidales del tipo de los cuecillos arcaicos y un recinto cuadrangular cercado por columnas basálticas no labradas -del tipo llamado, geológicamente, pentagonal-, en uno de cuyos extremos se encontraba un pequeño montículo con una cámara sepulcral, a manera de santuario, de muros y de techumbre columnaria pentagonal; sin embargo, a una arquitectura tan impresionantemente megalítica corresponden esculturas de un estilo evolucionado refinadísimo, como las figurillas de jade del estilo olmeca encontradas en la tumba -una de ellas pintada de rojo e incrustada con un disco de pirita-, que en modo alguno pueden calificarse de arcaicas. ${ }^{69}$

Para no minimizar su valor, sin embargo, Toscano prefería considerar a los olmecas como una "cultura, ante todo,

69 Toscano, Arte precolombino de México, p. 44. 
de escultores". ${ }^{70}$ Así, en un proceso evolutivo, el terrible arte de lo arcaico alcanzaba la arquitectura sublime de Teotihuacán y, finalmente, la decadencia del barroco maya. Con ello, Toscano intentaba insertar lo tremendo/monstruoso en los cánones universales de la estética.

Así, las apreciaciones sobre la calidad artística del pasado prehispánico no escaparon a los criterios universales y occidentales provenientes de la modernidad, su arte y ciencia. Como señala James Clifford, las posturas derivadas del relativismo no lograron escapar de la totalidad universal heredada del evolucionismo $y,{ }^{71}$ en el caso del arte prehispánico, quizá fuera por ello que nunca pudieron salir de la paradoja creada al igualar la belleza y la monstruosidad como elementos de definición.

No obstante, la interpretación de Toscano tuvo éxito y tal parece que la dimensión artística de las piezas no fue un tema que estuviera sujeto a debate. Por el contrario, la propuesta se ha generalizado alcanzado tanto el discurso oficial de la disciplina arqueológica, como el de algunas de las posturas más críticas sobre el autoritarismo y patrimonialismo del nacionalismo mexicano.

Alfonso Caso llegó a considerar que

[...] el libro de Toscano marca un punto de partida para una serie de investigaciones sobre el arte indígena del México

${ }^{70}$ Este criterio permanece actualmente. En la sala Culturas del Golfo del Museo Nacional de Antropología las esculturas rebasan por mucho el número de las vasijas expuestas. También se aclara al visitante que la cerámica del área no alcanza el "refinamiento" de las piezas de otros lugares que, incluso, retomaron elementos del estilo olmeca.

71 Clifford, Dilemas de la cultura. 
prehispánico, cubriendo un campo poco menos que inexplorado, el estudio de los objetos arqueológicos mexicanos, desde el punto de vista estético [...]. Estamos en presencia de una documentación amplia, sólida y perfectamente al día, lo que es bastante raro cuando se trata de libros sobre arte mexicano antiguo $[\ldots]^{72}$

Al poco tiempo la propuesta de Toscano también sería retomada por Ignacio Bernal en Esplendor del México antiguo, donde aseguraba que en los sitios de La Venta, Tres Zapotes y San Lorenzo "aparecieron las manifestaciones del primer gran arte de Mesoamérica, representado principalmente por su extraordinaria escultura en piedra". ${ }^{73}$ En este mismo sentido discursivo, actualmente el Museo Antropológico de Xalapa señala que los olmecas: "Produjeron algunas de las obras más tempranas y perfectas, estéticamente hablando, del mundo precolombino" ${ }^{74}$

Por otro lado, la postura de García Canclini resulta sumamente interesante. Si bien el autor piensa que la apreciación artística del arte prehispánico (como la mostrada en el Museo de Arte Prehispánico Rufino Tamayo) crea un ritual que elimina el sentido social de las piezas y privilegia la mirada culta, considera que los museos que lo exhiben han contribuido a acercar a las culturas, hacerlas conocerse entre sí y darnos

[...] pruebas visuales de una historia universal común. Al hacer patente que nuestro pueblo y nuestros antiguos artistas tienen

${ }^{72}$ Citado por Portilla en Toscano, Arte precolombino, p. 8.

73 Bernal, "Evolución y alcance", p. 105.

${ }^{74}$ Cédula introductoria, Museo Antropológico de Xalapa. 
una historia creativa, pero a la vez no son los únicos que crean, les debemos el haber hecho tambalear las mezquinas certezas del etnocentrismo mucho antes que los medios de comunicación masiva. ${ }^{75}$

No obstante, y en adelante, se mantiene la dificultad de la justificación de este discurso. Por ejemplo, Beatriz de la Fuente, en Los hombres de piedra, hizo un análisis de 15 de las cabezas colosales, en un intento por explicar la "armonía de sus proporciones”. En su estudio, la autora intentaba demostrar que las esculturas están regidas por un patrón matemático que les brinda la impresión de equilibrio, la armonía de sus partes y la belleza exacta de sus ritmos: la sección áurea: “[...] esta medida ideal simboliza el orden perfecto en la naturaleza y en el cosmos [...] No es de extrañar que los olmecas, al igual que otros pueblos creadores, hayan basado el ritmo constructivo de sus obras de arte en tal proporción”. Tomando como base el rectángulo áureo, ideal para una cabeza humana, De la Fuente hizo una clasificación de las cabezas colosales. De las 15, únicamente dos seguían el canon del "oro perfecto”. Por ello, la autora hizo algunas modificaciones al rectángulo áureo y así logró formar grupos y subgrupos que le permitieron encajar 11 de las cabezas restantes, mientras que las dos últimas (entre las que se encuentra la de Hueyapan) no pudieron ser encuadradas en ningún parámetro áureo. Ello implicaba, para la autora, que tales piezas fueron realizadas por personas ajenas a la cultura olmeca. ${ }^{76}$

75 García Canclini, Culturas híbridas, p. 164.

76 Fuente, Los hombres de piedra, p. 347. 
Y es que la universalidad intrínseca en la categoría "arte" torna imposible el ingreso de cualquier manifestación ajena a los parámetros de Occidente. Por ello Claudia Ovando asegura que "Resulta imposible juzgar el arte precolombino desde sus supuestos creadores si de entrada partimos del concepto de arte surgido en el seno de la cultura occidental en un punto específico en el tiempo -el Renacimiento-, para aprehender una serie de objetos que desde nuestra perspectiva consideramos como artísticos". ${ }^{77}$

La definición arqueológica de lo olmeca se hizo aún más compleja al incluir dentro de sus parámetros la categoría "estilo artístico" (introducida por Covarrubias y Toscano) que, por definición, se mantiene ajena al orden científico, moderno y racional al que aspiraba la disciplina. Si parte del valor estético se encuentra en su unicidad y en su carácter extraordinario (fuera de lo común), ¿cómo podría el arte significar un parámetro de observación y de interpretación válido para generalizar y caracterizar una cultura o un pueblo? Y ¿cómo, además, podría justificar la autenticidad de un pueblo si en sí mismo es un parámetro universal?

Quizá sea en los últimos años cuando este tipo de preguntas adquieren mayor peso y relevancia en el ámbito arqueológico. Entre el “estilo" y la "cultura”, los estudiosos no consiguen escapar de la paradoja. Recientemente, por ejemplo, De la Fuente señalaba:

$\mathrm{El}$ arte nos permite reconocer a los pueblos del pasado tanto en su singularidad como en su universalidad. No en vano podemos identificar a los grupos sociales, periodos y lugares

77 Ovando Shelley, “Arte precolombino”, p. 150. 
de origen mediante sus obras artísticas. De esta manera, resulta fácil distinguir el estilo pictórico pompeyano del estilo pictórico de Bonampak. Y acaso estamos ciertos sobre "el arte y el estilo olmecas", pero únicamente por lo que toca a la identificación de un modo de expresión que remite a los periodos Preclásico medio y tardío. Estos términos no implican la definición de un pueblo, de una región específica de origen ni de una cultura. ${ }^{78}$

Si el arte constituyó una herramienta conceptual fundamental para exhibir lo olmeca como el centro y el origen de todo el pasado civilizado precolombino, a la postre, también sería el centro del debate para poder explicar su presencia como cultura (pueblo) y su extensa presencia en el territorio nacional. ${ }^{79}$

\section{LO LOCAL}

Ramón Mena había reportado en 1916 la existencia de dos esculturas procedentes de Huimanguillo que se encontraban resguardadas en el Instituto Juárez de Tabasco. Una de éstas tenía rasgos negroides, mientras que la otra parecía de procedencia nahua. El profesor recomendaba iniciar las exploraciones en los alrededores y, a la vez, trasladar las piezas al Museo Nacional. Pese al interés de Mena, las esculturas, al igual que las cabezas colosales, nunca recorrieron el

78 Fuente, “¿Puede un estilo definir una cultura?”, p. 27.

$79 \mathrm{Al}$ menos desde la década de 1950 existieron diversas propuestas alternativas para comprender el llamado "estilo olmeca”. Así se propuso que la extensión de sus manifestaciones se debía a la imposición militar de un grupo cultural (Alfonso Caso), a la propagación de una religión (Román Piña Chan), etcétera. 
camino hacia la capital y el sitio de La Venta no fue explorado sino hasta la llegada de Matthew Stirling en 1939.

Como mencioné, sólo las piezas de jade fueron exhibidas en las primeras décadas del siglo xx, incluso en el extranjero, mientras que las esculturas de granito se quedaron en sus contextos originales, sin pisar el centro político del país. Esta segregación muestra parte del mecanismo centralista que rige el discurso de la disciplina arqueológica, el cual crea, en su interior, espacios centrales y periféricos. Este trato diferenciado representó el aislamiento de las esculturas en el discurso que se construía alrededor de la calidad artística y la superioridad evolutiva de la "cultura madre". No obstante, esta apreciación se modifica si se considera que la producción de significados también se encuentra en las localidades, las cuales sólo miradas desde el centro se muestran como zonas periféricas. ${ }^{80}$

Mucho antes de que se iniciara la planeación para remodelar el Museo Nacional de la ciudad de México, los monolitos de la costa adquirieron espacios y significados localizados. Fue en los poblados en los que se hallaron las esculturas en donde éstas tuvieron relevancia y notoriedad, sobre todo a mediados del siglo, cuando parte de la comunidad intelectual y artística se dio a la tarea de infundir un localismo nacional que (re)significó por completo algunas de las piezas de la llamada "cultura madre" en la entidad tabasqueña.

La pieza que antes reportara Ramón Mena en el Instituto Juárez, al parecer, fue trasladada a este lugar en 1896 por don

${ }^{80}$ Una reflexión sumamente interesante sobre el centro y la periferia en los análisis sobre la ciencia, en López BeLtrán, “Ciencia en los márgenes”, pp. 19-32. 
Policarpo Valenzuela, quien era concesionario de la industria maderera del lugar y había sido gobernador por varias ocasiones. Dio la escultura como regalo al entonces gobernador del estado, y fue este último quien la mandó colocar en el Instituto Juárez, junto con el monolito de varios rostros que también fuera reportado por Mena. ${ }^{81}$

El Instituto era uno de los lugares de orgullo para la élite de la población. En 1860, el gobernador del estado de Tabasco, Victorio Dueñas, había solicitado 50000 pesos para el establecimiento de un instituto de enseñanza secundaria, media y superior. Aunque su solicitud fue atendida favorablemente por el entonces presidente Juárez desde 1861, el proyecto se consolidó en enero de 1879. Casi un siglo después (en 1958) se transformó en universidad, y actualmente tiene nueve campus universitarios en Villahermosa y Cunduacán. ${ }^{82}$

La escultura donada por don Policarpo fue puesta en el patio del Instituto, y en 1910 se colocó sobre un pedestal. En este lugar se encontraba cuando fue observada y descrita por Ramón Mena durante su expedición y, cuando Frans Blom la fotografió en su viaje por los Tuxtlas en la década de 1920. Varias décadas después, Beatriz de la Fuente la describiría, desde la historia del arte, como una pieza que:

Rebasa la monumentalidad hasta alcanzar el gigantismo, es de recordar que se trata de un figura sentada de 1.73 metros de altura, y revela en su conformación, una vez más, la más pura

${ }^{81}$ Colorado, Juchimán, p. 28. Agradezco las facilidades brindadas por el doctor Miguel Ángel Díaz Perera para la obtención de este material.

$82 \mathrm{http} / /$ www.ujat.mx/conocenos/instituto_juarez/index.html, consulta electrónica realizada el 29 de mayo de 2009. 
composición geométrica. El cuerpo es una pirámide de planta cuadrada y vértice trunco, en donde encaja la gran cabeza rectangular. Los brazos son a la vez columnas diagonales y contornos limítrofes del espacio que recogen en su interior. Estructura configurada de acuerdo con los patrones olmecas ciñéndose a la más estricta economía de formas y de elementos. Hay, sin embargo, un ritmo interno de superficies curvas que le imprime un orgánico movimiento formal [...].

La figura se sienta conforme a la postura ritual: las piernas cruzadas, los brazos rectos extendidos hacia el frente y las manos apoyadas sosteniendo una barra contra el suelo. La enorme cabeza va coronada por un tocado que se ajusta sobre los ojos con una banda realzada, y que se ciñe por arriba a la extraña silueta del cráneo intencionalmente deforme con un abultamiento al frente y la parte superior alargada. El rostro, casi bestial, es ancho y de toscos rasgos. Los ojos profundamente rehundidos, están enmarcados, por arriba, por el grueso reborde de la banda del tocado; tienen forma de comas o ganchos en posición horizontal con las comisuras externas vueltas hacia dentro y hacia abajo. Los iris están perforados. La nariz es muy ancha y aplastada, y se apoya directamente sobre la boca cerrada de labios gruesos y carnosos ligeramente vueltos hacia afuera y con las comisuras hacia arriba.

Los pómulos son salientes y las mejillas hundidas, las orejas, angostas, largas y acanaladas. El cuello es, como se acostumbra representarlo, corto y grueso. El pesado y macizo cuerpo se inclina hacia adelante, describiendo un contorno curvo cuya contraparte es el eje diagonal marcado por los brazos. Al brazo izquierdo, en parte reconstruido, le falta la mano; en el contrario se conserva, y se ve cómo sostiene una barra gruesa situada a un nivel más bajo y por enfrente de las piernas. Es difícil precisar, debido a la erosión, si se trata de una mano o de una garra; el pulgar, al parecer echado hacia atrás, no es del todo visible. 
El Monumento 9 [sic] es una peculiar combinación de formas humanas vitalizadas por un principio animal. Pero hay en él no sólo algo de humano y de bestial, sino también de divino. Es como un ser poseído de un espíritu extraterrenal; en última instancia, es una magistral figura de piedra dotada por los maestros que la tallaron de profunda y misteriosa vida interior. ${ }^{83}$

Sin embargo, en el Instituto Juárez, la escultura tenía otros significados. De acuerdo con uno de los directores del establecimiento, el tabasqueño Belisario Colorado, con el paso de los años la pieza se convirtió en parte de la cotidianeidad de la vida estudiantil del recinto. Los estudiantes mostraban cariño por la escultura e, incluso, la utilizaban como testigo de sus travesuras al convertirla en sillón de peluquería para trasquilar a los novatos que ingresaban cada año.

La llamaron Juchimán y hasta la fecha se le conoce con este nombre (ilustración 1). Cuenta la leyenda que adquirió esta denominación gracias al ingenio bromista de un estudiante de apellido Zapata, quien degenerando el anglicismo watchman, bautizó a la escultura pétrea sedente en el patio como Juchimán haciendo alusión, a la vez, a los guardianes que en Tabasco son conocidos como guachimanes. ${ }^{84}$

Cierta o no la leyenda, Juchimán se convirtió en el centro de identidad del Instituto a mediados del siglo pasado.

83 Fuente, Los hombres de piedra, pp. 189-190.

${ }^{84} \mathrm{La}$ anécdota es relatada por Colorado, Juchimán, p. 29 ss. El mismo autor, con un claro orgullo y amor por la escultura y su estado natal, señala que el nombre de Juchimán actualmente "[...] es tan conocido como grato al oído tabasqueño, porque evoca el sordo rumor de las selvas, el llanto de los monos, el estentóreo grito del pájaro vaquero, el agudo chillido del pistoqué y el tristísimo y grave zurear de la paloma real: ¡Juuchi-mannn!”. 


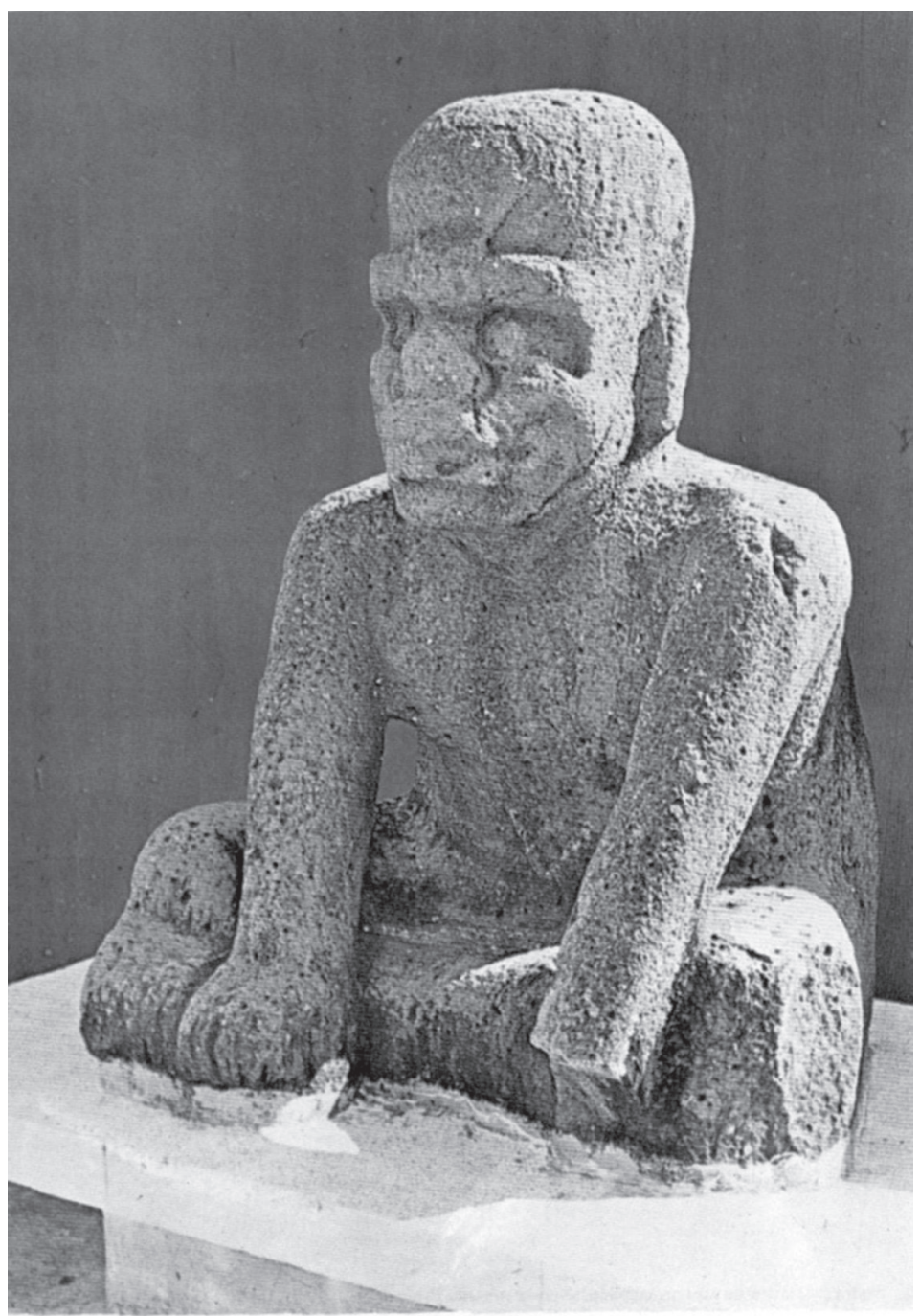


De acuerdo con Colorado, este reconocimiento fue en gran medida propiciado por él. En 1948, siendo director del establecimiento, usó el nombre de Juchimán para designar al equipo de voleibol y baloncesto, así como a la revista de la institución. También realizó el primer escudo para la escuela usando la silueta del personaje, y propició la venta de banderines, ropa deportiva y reproducciones del ídolo. ${ }^{85}$

El uso de la imagen de la escultura tenía un significado sumamente profundo para el profesor, más allá de que los estudiantes en sus travesuras lo consideraran un guachimán del Instituto. Juchimán se encontraba en el patio, a un lado de un monumento a Benito Juárez, patrono del instituto, y Colorado vio en esta cercanía una oportunidad de creación simbólica. En 1949, para la celebración del aniversario del natalicio del Benemérito, el Instituto preparó un carro alegórico que soportaba una pirámide que, a su vez, servía como base para mostrar una réplica del monumento a Juárez y, además, una a escala natural del "centinela Juchimán”. Los ídolos fueron custodiados por alumnas del instituto disfrazadas de indígenas y, para Colorado, el carro alegórico "fue el mejor y más admirado y aplaudido del homenaje a Juárez aquel 21 de marzo de 1949”.

La representación montada por Colorado no era la simple ocurrencia de reunir las esculturas resguardadas en el patio del Instituto. Por el contrario, el profesor quería crear la base simbólica de la comunidad tabasqueña en la institución: “Juchimán’, el autóctono monolito tabasqueño, búdicamente sentado al pie del monumento del gran Benemérito

85 La escultura es llamada ídolo por Colorado. Conservo aquí esta designación. 
de las Américas, parece marcar el alfa de nuestras razas indígenas, cuya omega es Juárez; por eso tenía que figurar en el Escudo este enigmático y popular personaje del Instituto" ${ }^{86}$

El carro alegórico condensaba así el más antiguo esplendor "indígena" con el mayor logro alcanzado varios cientos de años después por la misma raza (Juárez), y con estos símbolos se narraba también uno de los constructos de los regímenes posrevolucionarios. En un intento por salvar la tensión existente entre la universalidad y la localidad, los dos extremos de la historia recorrían, en el carro alegórico, las calles de aquel lugar en el que toda la civilización americana había iniciado: Tabasco.

Ignoro en qué proporción fue aceptada y continuada la alegoría creada por Colorado y si ésta trascendió con tal fuerza en el resto de la comunidad del instituto. Sin embargo, me parece posible considerarla un éxito notable debido a que actualmente la escultura mantiene un lugar central para la institución. Hoy en día Juchimán es, para los tabasqueños, la representación de Ixtlitón, el "rey de las aguas negras". Ocupa la parte central del escudo de la ahora Universidad de Tabasco, diseñado por Carmen Sosa viuda de Velásquez. En el emblema, con un águila bicéfala como fondo, Juchimán se encuentra sosteniendo el blasón oficial del estado de Tabasco y, a sus pies, está el lema de la universidad: Estudio en la duda, acción en la fe (ilustración 2).

La escultura sigue colocada sobre un pedestal y se encuentra enmarcada por uno de los arcos del Instituto Juárez, en el centro de Villahermosa; los universitarios se consideran "juchimanes", e incluso existe un premio con su

${ }^{86}$ Colorado, Juchimán, pp. 48-49. 


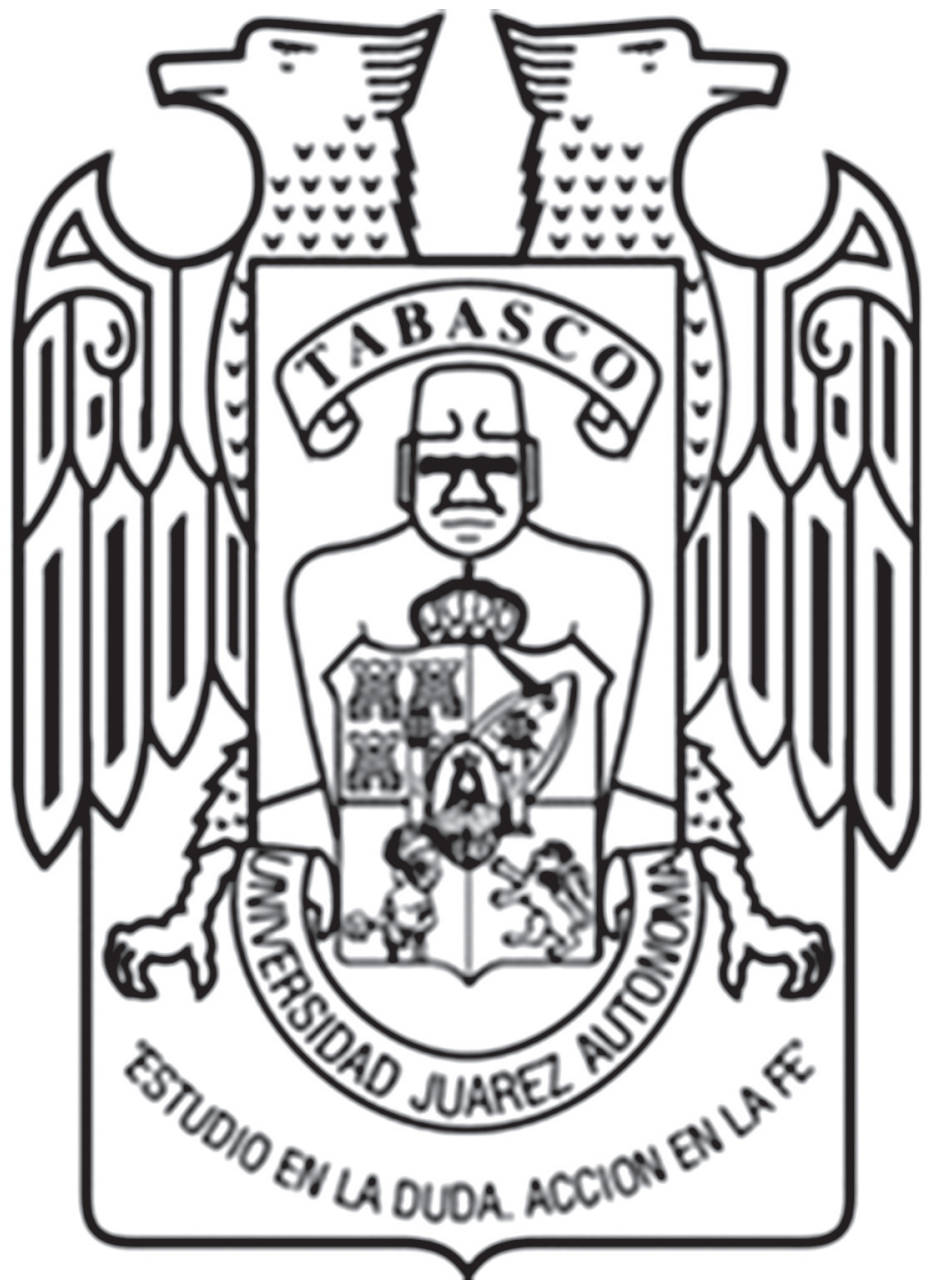


nombre: "Juchimán de plata", presea que otorga el Consejo Directivo de Juchimanes de Plata, A. C. y la Universidad Juárez Autónoma de Tabaco a quienes hayan contribuido a enriquecer el legado cultural y social de Tabasco y del país. ${ }^{87}$

Pese a que en gran medida podría considerarse que esta resignificación nació de un criterio personal, no podría asegurarse que su consolidación fuese gratuita. En buena medida la creación y aceptación de Juchimán como símbolo tabasqueño responde a la ideología impulsada por el grupo de élite del estado de mediados de siglo.

Poco después de que Juchimán acompañara al Benemérito por las calles tabasqueñas, Colorado, en su calidad de diputado local, facilitó el recorrido de Carlos Pellicer Cámara (1897-1977) por las ruinas de La Venta, Tabasco. Como uno de los jóvenes intelectuales favorecidos por el régimen, Pellicer había sido becado en 1925 por Puig Cassauranc para realizar sus estudios en París. Viajó por Europa hasta 1929, y más tarde regresó al país. En 1941 se integró como jefe del Departamento de Bellas Artes y, al año siguiente y hasta 1946, trabajó como subdirector general de Educación Extraescolar y Estética del Palacio de Bellas Artes. ${ }^{88}$ Además de su exitosa carrera literaria y en la administración de la cultura y las artes, Pellicer tuvo aficiones que lo ligaron al

${ }^{87}$ Entre los galardonados con este premio se encuentran figuras como: Lucio Mendieta y Núñez, Luis Cardoza y Aragón, Carlos Quijano, Leopoldo Zea Aguilar, Jaime García Terrés, Eduardo Nicol, Ramón Xirau, Fernando Tola de Habich, Miguel León Portilla, Beatriz de la Fuente Ramírez, Federico Reyes Heroles, Luis Villoro y Rubén Bonifaz Nuño. http://www.dgi.unam.mx/boletin/bdboletin/2005_012.html, consulta electrónica realizada el 29 de mayo de 2009.

${ }^{88}$ Sus datos biográficos en Pellicer y Reyes, Correspondencia, 19251959. 
pasado prehispánico y gracias a ello se convirtió en uno de los más grandes coleccionistas de antigüedades de la época, junto con Diego Rivera y Miguel Covarrubias.

En 1951, junto con Colorado y el entonces gobernador del estado, Francisco Javier Santamaría (1866-1963), el presidente municipal de Huimanguillo, Ignacio Flores, y algunos otros funcionarios locales, Pellicer recorrió la zona arqueológica de La Venta. Salieron de Villahermosa en una vieja avioneta y continuaron el recorrido en un jeep desechado de la segunda guerra mundial y, luego, en una lancha de motor. Los últimos kilómetros los recorrieron a pie, bajo el sol quemante y las nubes de insectos:

[...] al llegar al claro del bosque donde yacía la Cabeza Sonriente, Pellicer se quedó estático como otra piedra, hasta que cobró aliento y lanzó un grito estentóreo que toda la selva repitió; luego quiso correr hasta el monolito, pero se enredó en los bejucos y maleza y cayó de rodillas como en adoración, se levantó de un salto felino ¡y la tocó! Después, sin importar la amenaza de víboras ni insectos, se dio a correr y gritar alrededor de la mole aquella [...] Cuando se detuvo por falta de aliento, Pellicer se dirigió a nosotros, acezando y desencajado, con los ojos llameantes y, a manera de un juramento, exclamó: ¡Señores, esta piedrecita me la llevo yo! ${ }^{89}$

El paseo por la selva fue el inicio de la planeación para la reorganización del Museo de Tabasco que llevó el nombre del poeta. El proyecto le fue encomendado por el maestro Santamaría, quien durante toda su gestión como gobernador impulsó el desarrollo de los espacios culturales en el estado.

${ }^{89}$ Colorado, Juchimán, pp. 23-24. 
Se pensaba establecer el museo en los portales de Villahermosa, pero ante la pequeñez del local, Pellicer solicitó el edificio construido durante la gestión anterior en la Plaza de Armas. Si bien el espacio había sido erigido años atrás para funcionar como Escuela Tecnológica, la carencia de hasta los equipos más básicos impidió su funcionamiento, por lo que no fue difícil que las autoridades lo destinaran para el uso que proponía Pellicer. Lo que sí resultó difícil fue convencer al Instituto Juárez para ceder a Juchimán al Museo. Colorado recuerda que:

Cuando Pellicer instaló a la entrada del flamante museo la Sala de La Venta, ya le había echado el ojo terco y perspicaz a Juchimán. Y empezó a quererme convencer, como director del instituto para que lo cediera al Museo. Una vez me invitó a conocer aquella Sala de La Venta [...]. De repente se detuvo teatralmente frente a una base o pedestal vacío y, como dirigiéndose a un auditorio juzgador, con voz solemne me dijo: “Aquí va Juchimán; pero si usted no lo entrega quedará como un ripio, un reproche contra usted". ${ }^{90}$

La amenaza, sin embargo, no surtió efecto y Colorado no autorizó el traslado de la escultura. Pero Pellicer no cedería ni olvidaría su capricho tan fácilmente. Una vez que Colorado fue sustituido en la dirección de Instituto por Julián A. Manzur Ocaña, el poeta volvió a hacer su solicitud, extendiendo su petición a una instancia superior: la gubernatura del estado. Sólo así consiguió la donación de Juchimán para el Museo. Aprovechando los días de vacaciones de la institución, Pellicer fue armado con un camión de plataforma

${ }^{90}$ Colorado, Juchimán, p. 52. 
para sacar la escultura del recinto. Sin embargo, los estudiantes, al enterarse de sus intenciones, acudieron amenazantes para impedir el acto. Pese al enfado de Pellicer, la escultura no se trasladó y el Museo se inauguró sin Juchimán el 19 de noviembre de 1952.

Este episodio no sólo responde a las actitudes o caprichos personales (de Pellicer por su ideal histórico museográfico, o de la comunidad vinculada afectivamente a la escultura), sino que constituye una faceta del proceso de apropiación de los bienes arqueológicos y de su (re)valoración histórica y estética por parte de las localidades.

Las localidades del la Costa del Golfo no estaban exentas de los intereses de conservación por parte de las entidades centrales. En la inspección que hiciera Rubín de la Borbolla a La Venta en 1945, se observan este tipo de preocupaciones. El antropólogo reportó que muchos de los monumentos habían sido objeto de constante vandalismo por los visitantes de los alrededores (Agua Dulce, Las Choapas e incluso los trabajadores de La Venta). Los monumentos presentaban huellas de golpes, rayaduras de letras y nombres y numerosas despostilladuras. La situación era grave, pues pese a que el guardián de la zona había puesto letreros prohibiendo la destrucción de las piezas, sólo consiguió que estos avisos también fueran destruidos. ${ }^{91}$

Esta situación se hizo más compleja ante el saqueo de la zona, probablemente motivada por la publicidad que recibieron los hallazgos hechos durante las excavaciones de Matthew Stirling. Casi una década después de la visita

91 ATA, Smithsonian reportes, t. CLXXII, exp. 32. "Informe La Venta Tabasco", Ms., 2 pp., 14 de julio de 1945. 
de Rubín de la Borbolla, Juan Valenzuela remitió al Departamento de Monumentos una enérgica queja sobre la destrucción del patrimonio. Su visita al lugar había ocurrido a casi un año de que "el famoso tesoro artístico [las 782 piezas de jade]" estuviera recorriendo los principales países de Europa. De acuerdo con Valenzuela, los restos eran destruidos por numerosos "desmanes que hemos calificado de actos bochornosos". Siempre hablando de los restos en general, Valenzuela argumentaba que numerosos artículos de la ley protegían ese patrimonio, pero que esto resultaba insuficiente y que, por ello, era necesario brindar mayor vigilancia a los monumentos:

A mayor abundamiento sabemos que los mejores ejemplares de tipo olmeca de jade de la mayor calidad y en abundancia, han salido precisamente en su mayoría de esos montículos de tierra, pobres si se quiere en lo que se refiere a la arquitectura, pero riquísimos en otros aspectos y son esas construcciones de tierra los que más tienden a desaparecer. ${ }^{92}$

La inquietud de proteger los restos patrimoniales por medio de su custodia y exhibición no fue exclusiva de los inspectores de la ciudad de México. Al poco tiempo de que se abriera el Museo de Tabasco, en la capital veracruzana también se comenzó la planeación de un nuevo recinto que albergaría parte de las colecciones que hasta ese momento se encontraban en la Universidad Veracruzana. El Museo de Antropología de Xalapa, construido en 1960, actualmente

92 ATA, Smithsonian reportes, t. CLXXII, exp. 33. Correspondencia Juan Valenzuela-Director de Monumentos Prehispánicos, Ms., 5 pp., 27 de febrero de 1953. 
custodia siete cabezas colosales, así como numerosas piezas tanto de la cultura olmeca como de otros importantes desarrollos del estado. ${ }^{93}$

De igual manera y al poco tiempo (1974), se erigió un museo en la localidad de Tres Zapotes, Veracruz, con "el propósito de resguardar el valioso legado escultórico que nos dejaron los antiguos habitantes de esta región". ${ }^{94} \mathrm{De}$ esta forma, el visitante puede observar buena parte de las esculturas que fueron localizadas por Stirling durante sus exploraciones. En este espacio también se exhiben varias fotografías de la misma expedición, las cuales recuperan el imaginario del explorador incansable que no se vence ante la adversidad de tierras desconocidas. ${ }^{95}$

Es cierto que la apertura de cada uno de estos museos responde a la preocupación de las entidades centrales por la protección del patrimonio, pero también lo es que cada uno de estos espacios se vio favorecido por el interés de cada localidad en apropiarse y (re)significar un fragmento de la historia patria y nacional. En esta tarea, las acciones

${ }^{93}$ La información sobre el Museo de Antropología de Xalapa, en LADrón DE Guevara, "El Museo de Antropología de Xalapa”, pp. 10-11; y Guía, p. 10 ss.

${ }_{94}$ Cédula Museográfica, Museo de Tres Zapotes, Santiago Tuxtla, Veracruz.

${ }^{95}$ Las fotografías que se exhiben en las salas fueron recuperadas del National Geographic Magazine. Cabe mencionar, por otro lado, que en el Museo Tuxteco de Santiago Tuxtla también se exhiben dos cabezas colosales y otras piezas de basalto. De acuerdo con la información procedente del Sistema Nacional de Fototecas, alrededor de la década de 1950 había dos cabezas en los jardines de San Andrés Tuxtla y Santiago Tuxtla (fotografías núm. inventario: 300189 y 309531 ). Sin embargo, me parece que la identificación es errónea y ambas piezas en realidad se ubicaron en Santiago (y no en San Andrés), en donde permanecen hasta la actualidad. 
federales se vieron complementadas y fortalecidas por el entusiasmo de los grupos intelectuales y políticos de cada estado, y fue este último el que hizo posible la edificación de sitios que, si bien, mantienen el discurso general sobre la historia nacional, enfatizan cierto chauvinismo localizado.

Por otro lado, también es posible observar en estos episodios la fuerte liga que existió entre estos intelectualesartistas, como Pellicer, y la comunidad de arqueólogos. No en pocas ocasiones el discurso generado por aquéllos tuvo repercusiones profundas en la construcción de la historia prehispánica y viceversa. ${ }^{96}$ La presencia de Covarrubias y Toscano en la Mesa Redonda de 1942 tuvo una innegable importancia para la definición de la "cultura madre". Pellicer, por su parte, sería el artífice en gran medida de la historia local de esos mismos restos, transmutando su significado en la historia nacional a uno localizado en la región, delineado por su capricho estético personal.

$\mathrm{Al}$ poco tiempo de inaugurar el Museo Pellicer, el poeta tabasqueño se enfrascó en un nuevo reto que manifiesta en buena medida este orgullo nacional localizado. En 1952 fue nombrado director de los museos de Tabasco y, por estas fechas, inició lo que quizá fuera su proyecto más ambicioso en el terreno de la museografía arqueológica: pensaba recrear el paisaje que creyó podían haber ocupado los olmecas en su tiempo. Para ello trasladaría los monolitos desde La Venta y ejemplares de flora y fauna a un espacio de 7 ha destinado para tal fin en la capital del estado. A su amigo Alfonso Reyes, en septiembre de 1957, le comentaba lo siguiente:

96 Un trabajo pionero en Rodríguez, "El pasado indígena”. 
Cuando yo regrese a la capital iré a verte y te platicaré de la cosa en que ando metido: aquí ando moviendo y trasladando milenios hasta de 38 toneladas. ¡Oyeras cómo crujen! Y cuando se acomodan sobre la plataforma del "Mack", el que sigue crujiendo soy yo. Figúrate que cuando moví la Gran Piedra Triunfal -esa de 38 toneladas- pasé la noche sentado pensando que la formidable escultura venía por la carretera a razón de 20 kilómetros por hora y desde una lejanía de más de 150 kilómetros. Ya he trasladado 15 monumentos. Me faltan aún 5 esculturas -una de ellas de cerca de 50 toneladas (ociosidades del volumen)- más un sepulcro megalítico y un gran sarcófago -atascado de siglos-. He tenido que ponerme a régimen para envejecer lo suficiente y estar a tono con estas piedras maravillosas que por ser casi desconocidas, cuando yo dé por terminada la mise en public [sic] asombrarán a los mundos.

Pero hombre: figúrate un poema de siete hectáreas. Con versos milenarios y encuadernados en misterio. Naturalmente a orillas de un lago con algunos errores llamados cocodrilos. La Settimana [sic] ventura soltaré allí mismo catorce venados que le darán rápida puntuación a tan magnífico texto. Aquí en Tabasco ya sabes que se hila muy delgado. Cuando vas a cortar una flor, se te va pues resultó ser mariposa, y viceversa. No somos culpables. ¡Allá el sol! En el mismo predio estoy organizando un zoológico con las solas especies tabasqueñas. Tenemos un pájaro que es como la paleta olvidada de un pintor muy joven. También el tapir que es un proyecto descalificado de rinoceronte. Con muy poco esfuerzo completaré lo botánico y desa manera los tres reinos estarán en mí. Y te digo en mí porque ya toda esta negocia [sic] es parte de mi cuerpo.

Todo este manoseo de siglos a la luz del día me ha confirmado que hay que pasar la vida jugando. Claro, jugando y conjugando, y nada de participios: a darle que es gerundio. Pobres de los que se empeñan en jugar en serio, porque [...] están 
Xodidos. Porque mira Alfonsito: Cuando yo hace cinco años pensé en la chingamusa ésta, me dije: ¡a ver qué sale! Y claro, lo que ha salido es una cosa tremenda, pero deliciosa $\mathrm{Y}$ es la obra de mi vida. Estoy haciendo un poema con los tres reinos y mucho Hombre. En pequeños refugios de jahuacte y huano -caña y palmera- contra la lluvia o el calor habrá libros de madera con techos brevísimos sobre la Naturaleza y el alma. Cuando quieras escríbeme algunas -frases, bien entendidoque haré incidir sobre planchas delgadas de maderas preciosas. Así, el visitante bueno o malo, tendrá que fregarse y encontrará su sitio. Como ves, a lo mejor todo esto va a resultar bien sabroso. Claro, habrá aguas frescas de frutas tropicantables y a escondidas venderemos Coca-Colas con mentadas de madre. Dentro de un mes regresaré -Dios mediante- a Las Lomas y llamaré por teléfono para ir un día a detallarte más esta información. ¡Aunque te duermas! Y el Parque Museo-Poema de La Venta, en esta fea Villahermosa no lo podré terminar sino hasta junio venidero. Pero ya está muy adelantado. ${ }^{97}$

Lo terminó, en efecto, el siguiente año y fue inaugurado el 4 de marzo de 1958 por el presidente Adolfo Ruiz Cortines. Se llamó Parque Arqueológico La Venta, y se ubicó a las orillas de la laguna de Las Ilusiones, en Villahermosa. Todas las esculturas localizadas por Stirling, incluyendo las tumbas de mosaicos de jade y las columnas de basalto, fueron reubicadas en el Parque de La Venta, dejando en la zona arqueológica únicamente réplicas manufacturadas en fibra de vidrio de algunos de los monolitos originales. ${ }^{98}$

97 Pellicer y Reyes, Correspondencia, 1925-1959, pp. 60-61.

98 Se inauguró como una institución dependiente del Gobierno del Estado de Tabasco, y desde 1984 forma parte del Instituto de Cultura. 
A lo largo de un camino serpenteante, el visitante puede observar, a un lado y al otro, las esculturas de fija mirada inmersas en un nuevo significado. El poeta no sólo concibió un espacio que resaltara la localidad del inicio de la historia prehispánica, sino que trató de escapar del orden tradicional, científico y nacional. Mientras que los museos cerrados buscaban desvelar el orden que subyacía a las piezas, Pellicer quería replicar el orden natural evidente para los sentidos. En la recreación de la selva y el sitio, la naturaleza y lo humano se hacen presentes, mas, cual si fuera una obra teatral, tras bambalinas se oculta la imposición artificial del montaje localizado tramado por Pellicer.

La historia de los diversos significados de las piezas arqueológicas hoy conocidas como olmecas no corresponde de manera mecánica al desarrollo progresivo de los descubrimientos científicos, sino que también ha estado acompañada por los ideales de los siglos XIX y xx, evidenciando parte de los intereses y algunas de las múltiples inquietudes que tuvo la reconstrucción del ideal nacional y la historia patria, proceso que fue heterogéneo, lleno de cuestionamientos e inquietudes que plantearon diversas alternativas de construcciones históricas a lo largo del tiempo.

Beauregard Solís, "Datos históricos sobre el Parque-Museo de La Venta", pp. 61-67.

Si bien uno de los objetivos básicos de Pellicer fue resguardar las piezas que estaban en constante peligro de destrucción por el crecimiento de la industria petrolera, sus acciones tuvieron un efecto perjudicial para la zona arqueológica. Esta última ha sufrido un paulatino abandono, explicable si se considera que carece de mayores atractivos visuales (además de la pirámide de tierra que difícilmente es comprendida por el público lego), con réplicas destruidas y descuidadas, rodeada por la urbanización y sin transporte que facilite el acceso desde otros puntos del estado. 
En este sentido, la presencia negra en el continente americano, si bien aseguraba un contacto remoto con Europa, ante el miedo racista del momento, no resultaba útil para repeler los argumentos eurocentristas sobre la degeneración de las razas americanas. Tampoco pudo competir con el centralismo de la historia patria basada en la cultura mexica. Luego, los anhelos del periodo de entreguerras fueron el caldo de cultivo idóneo no sólo para afianzar una disciplina en ciernes como la arqueología, sino para redireccionar la genealogía del pueblo mexicano hacia un origen no sólo remoto, sino también "civilizado", como la "cultura madre". En esos momentos, los cánones del arte y los anhelos e intereses de algunos artistas, que mezclaron su actividad con la academia arqueológica, crearon vínculos importantes para la disciplina arqueológica y la narrativa que estaba construyendo. Analizar a profundidad estos vínculos entre las comunidades arqueológica y artística es una veta fundamental, pero pendiente para la arqueología, así como para la historia de las resignificaciones que ha sufrido el patrimonio. Finalmente, los intereses de algunos políticos e intelectuales a nivel local también incidieron en esta cadena de recreaciones, realizando un contrapeso a la historia creada desde el centro, y proponiendo otros parámetros (personales) para la construcción de la historia.

Así, las historias creadas y reformuladas algunas veces se sustituyeron entre sí, y otras más, se traslaparon, creando modificaciones no sólo en las historias nacional y local, sino también en la exhibición museográfica, y en la apreciación del patrimonio y la estética de las piezas arqueológicas a lo largo de los siglos xix y xx. 


\section{SIGLAS Y REFERENCIAS}

ATA Archivo Técnico de Arqueología, Coordinación Nacional de Arqueología, Instituto Nacional de Antropología e Historia, México.

IIA-UNAM, $A C A \quad$ Instituto de Investigaciones Antropológicas, Universidad Nacional Autónoma de México, fondo $\mathrm{Al}$ fonso Caso Andrade.

Aveleyra Arroyo de Anda, Luis

Obras selectas del arte prehispánico (adquisiciones recientes). Consejo Nacional para la Planeación e Instalación del Museo Nacional de Antropología, México, fotografías de Irmgard Groth-Kimball, Secretaría de Educación Pública, 1964.

"Los cazadores del mamut, primeros habitantes de México", en Esplendor del México antiguo, t. I, pp. 53-72.

BARTRa, Roger

El salvaje artificial, México, Universidad Nacional Autónoma de México, Ediciones Era, 1997.

BATRES, Leopoldo

Exploraciones de Monte Albán, México, Casa Editorial Gante, 1902.

Beauregard Solís, Graciela

"Datos históricos del parque-Museo de La Venta", en Kuxulkab Revista de Divulgación, VII (14) (2000), pp. 61-67.

Bernal, Ignacio

"Evolución y alcance de las culturas mesoamericanas", en Esplendor del México antigno, t. I, pp. 97-124.

El mundo olmeca, México, Porrúa, 1991. 
Boswell, David y Jessica Evans

Representing the Nation: A Reader. Histories, Heritage and Museums, Londres, Routledge, 1999.

Caso, Alfonso

Thirteen Masterpieces of Mexican Archaeology, México, Cultura y Polis, 1938.

Castro-Leal, Marcia y Dora Sierra

“Museo Nacional de Antropología”, en García Mora (coord.), 1988, pp. 511-559.

Chavero, Alfredo

“Primera época. Historia antigua”, en Riva Palacio, 1981.

Clifford, James

Dilemas de la cultura. Antropología, literatura y arte en la perspectiva posmoderna, traducción de Carlos Reynoso, Barcelona, Gedisa, 1995.

Colorado, Belisario

Juchimán. Biografía de un ídolo viviente, México, Dirección de Difusión Cultural y Extensión Uiversitaria, Universidad Juárez Autónoma de Tabasco, 1991.

Congrés international des américanistes

Congrés international des américanistes: compte-rendu de la première session, Nancy-1875, t. I, Nendeln, Liechtenstein, Kraus Reprint, 1968. Congrés international des américanistes: compte-rendu de la première session, Nancy-1875, t. II, Nendeln, Liechtenstein, Kraus Reprint, 1968.

Соттом, Bolfy

Nación, patrimonio cultural y legislación: los debates parlamentarios y la construcción del marco jurídico federal sobre monumentos en México, siglo XX, México, Miguel Ángel Porrúa, Cámara de Diputados, 2008. 
Covarrubias, Miguel

“Origen y desarrollo del estilo artístico 'olmeca'”, SMA, Mayas y olmecas. Segunda Reunión de Mesa Redonda sobre problemas antropológicos de México y Centroamérica, Tuxtla Gutiérrez, Chiapas, México, Talleres de la Editorial Stylo, 1942, p. 46.

El sur de México, edición facsimilar de la de 1980, México, Instituto Nacional de Estudios Históricos de la Revolución Mexicana, 2004.

Duncan, Carol

"From the Princely Gallery to the Public Art mMuseum: the Louvre Museum and the National Gallery, London", en Boswell y Evans, 1999, pp. 304-331.

Esplendor del México antiguo

Esplendor del México antiguo, México, Centro de Investigaciones Antropológicas de México, 1959, 2 volúmenes.

Fuente, Beatriz de la

Los hombres de piedra. Escultura olmeca, México, Universidad Nacional Autónoma de México, 1984.

“¿Puede un estilo definir una cultura?”, en URIARTE y GonZÁlEZ LAUCK (eds.), 2008, pp. 25-37.

Gamio, Manuel

Forjando patria, prólogo de Justino Fernández, México, Porrúa, 1960.

Ganz, Cheryl

The 1933 Chicago World's Fair. A Century of Progress, Chicago, University of Illinois Press, 2008.

García Canclini, Néstor

Culturas híbridas. Estrategias para entrar y salir de la modernidad, México, Consejo Nacional para la Cultrua, Grijalbo, 1989. 
García Mora, Carlos (coord.)

La antropología en México. Panorama histórico, vol. 7 Las instituciones, México, Instituto Nacional de Antropología e Historia, 1988.

Guía

Guía Oficial Museo de Antropología de Xalapa, Gobierno del Estado de Veracruz, Universidad Veracruzana (eds.), México, Editorial del Gobierno del Estado de Veracruz, 2004.

НовSвашм, Eric

Historia del siglo XX, Barcelona, Crítica, 2007.

Jiménez Moreno, Wigberto

"El enigma de los olmecas", en Cuadernos Americanos, v: 5 (sep.-oct. 1942), pp. 113-145.

"Síntesis de la historia pretolteca de Mesoamérica”, en Esplendor del México antiguo, 1959, t. II, pp. 1019-1108.

Ladrón de Guevara, Sandra

"El Museo de Antropología de Xalapa”, en Arqueología Mexicana (edición especial), Museo de Antropología de Xalapa, 22 (2006), pp. 10-11.

López Beltrán, Carlos

"Ciencia en los márgenes: una reconsideración de la asimetría centro-periferia”, en Rutsch y Serrano, 1997, pp. 19-32.

Melgar y Serrano, José María

"Antigüedades mexicanas", en Boletín de la Sociedad Mexicana de Geografía y Estadística de la República Mexicana, segunda época, t. I, México, Imprenta del Gobierno en Palacio a cargo de José María Sandoval, 1869, pp. 292-297.

"Estudio sobre la antigüedad y el origen de la cabeza colosal de tipo etiópito que existe en Hueyapam, del Cantón de los Tuxtlas, por el C. José M. Melgar”, en Boletín de la Sociedad Mexicana de Geografía y Estadística de la República Mexi- 
cana, segunda época, t. III, México, Imprenta del Gobierno en Palacio a cargo de José María Sandoval, 1871, pp. 104-118. Juicio sobre lo que sirvió de base a las primeras teogonías. Traducción del manuscrito mayo perteneciente al Señor Miró. Observaciones sobre algunos otros datos encontrados en los monumentos y manuscritos mejicanos, que prueban las comunicaciones antiquísimas que existieron entre el viejo y nuevo mundo, Veracruz, México, Imprenta de R. de Zayas, 1873.

Mena, Ramón

Catálogo de la colección de objetos de jade, edición facsimilar de la de 1927, México, Instituto Nacional de Antropología e Historia, 1990.

Millón, René

"La agricultura como inicio de la civilización”, en Esplendor del México antiguo, 1959, t. II, pp. 997-1018.

Morales Moreno, Luis Gerardo

Orígenes de la museología mexicana. Fuentes para el estudio histórico del Museo Nacional, 1780-1940, México, Universidad Iberoamericana, 1994.

Opiniones

Opiniones de distinguidas personas que vieron la exposición de las joyas de Monte Albán en los Estados Unidos de América, México, Publicaciones del Museo Nacional, 1934.

Ovando Shelley, Claudia

"Arte precolombino: entre la belleza y la monstruosidad", en Trejo y Matute (eds.), 2005, pp. 145-159.

Pellicer, Carlos y Alfonso Reyes

Correspondencia, 1925-1959, Serge I. Zaïtzeff (ed.), México, Ediciones El Equilibrista, Consejo Nacional para la Cultura y las Artes, 1997. 
Pérez Montfort, Ricardo

"El Museo Nacional como expresión del nacionalismo mexicano”, en Alquimia, 4: 12 (mayo-ago. 2001), pp. 27-31.

Pérez Vejo, Tomás

España en el debate público mexicano: 1836-1867: aportaciones para una hisoria de la nación, México, El Colegio de México, Instituto Nacional de Antropología e Historia, 2008.

Rico Mansard, Luisa Fernanda

Exhibir para educar. Objetos, colecciones y museos de la ciudad de México (1790-1910), Barcelona, Ediciones Pomares, 2004.

Riva Palacio, Vicente

México a través de los siglos. Historia general y completa del desenvolvimiento social, político, religioso, científico y literario de México desde la antigüedad más remota hasta la época actual, ts. I y II, edición facsimilar, México, Cumbre, 1981 [1889].

Rodríguez Mortellano, Itzel Alejandra

"El pasado indígena en el nacionalismo posrevolucionario. El mural México antiguo (1929) de Diego Rivera en el Palacio Nacional", tesis de maestría en historia, México, Universidad Nacional Autónoma de México, 2004.

Rozat, Guy

Los orígenes de la nación: pasado indígena e historia nacional, México, Universidad Iberoamericana, 2001.

Rutsch, Mechthild

Entre el campo y el gabinete. Nacionales y extranjeros en la profesionalización de la antropología mexicana (1877-1920), México, Instituto Nacional de Antropología e Historia, Universidad Nacional Autónoma de México, 2007. 
Rutsch, Mechthild y Carlos Serrano

Ciencia en los márgenes. Ensayos de historia de las ciencias en México, México, Universidad Nacional Autónoma de México, 1997.

RydeLL, Robert

“The Chicago World's Columbian Exposition of 1893: 'And Was Jerusalem Builded Here?’”, en Boswell y Evans, 1999, pp. 273-303.

SAville, Marshall

"Votives Axes from Ancient Mexico", en Indian Notes, vi: 3, s/f, pp. 266-299.

"Votive Axes from Ancient Mexico II", en Indian Notes, vi: 4 (oct. 1929), pp. 335-342.

Sociedad Mexicana de Antropología (sma)

Mayas y olmecas. Segunda Reunión de Mesa Redonda sobre problemas antropológicos de México y Centroamérica, Tuxtla Gutiérrez, Chiapas, México, Talleres de la Editorial Stylo, 1942.

Stirling, Matthew

"Discovering the New World's Oldest Dated Work of Man. A Maya Monument Inscribed 291 B. C. is Unearthed Near a Huge Stone Head by a Geographic-Smithsonian Expedition in Mexico", en The National Geographic Magazine, Lxxvi: 2 (1939), pp. 183-218.

Tenorio Trillo, Mauricio

Artilugios de la nación moderna. México en las exposiciones universales, 1880-1930, México, Fondo de Cultura Económica, 1998.

Toscano, Salvador

Arte precolombino de México y de la América Central, prólogo del doctor Miguel León Portilla, México, Universidad Nacional Autónoma de México, 1970. 
Trejo, Evelia y Álvaro Matute (eds.)

Escribir la bistoria en el siglo XX. Treinta lecturas, México, Universidad Nacional Autónoma de México, 2005.

Uriarte, María Teresa y Rebeca González Lauck (eds.)

Olmeca. Balance y perspectivas. Memoria de la Primera Mesa Redonda, 2 tomos, México, Universidad Nacional Autónoma de México, Consejo Nacional para la Cultura y las Artes, Instituto Nacional de Antropología e Historia, Fundación Arqueológica del Nuevo Mundo, Universidad Brigham Young, 2008.

Vaillant, George Clapp

"Excavations at Zacatenco", en Anthropological Papers of the American Museum of Natural History, xxxII, parte I (1930), pp. 23-139.

"Visita"

"Visita al Museo Nacional", en Actas de la XI Reunión del Congreso Internacional de Americanistas, México, 1895, Nendeln, Liechtenstein, Kraus Reprint, 1968, p. 37. 